\title{
Komunikasi Publik Ormas Keagamaan Islam terkait Social Distancing pada Masa Pandemi COVID-19 (Studi atas Sikap Resmi NU, Muhammadiyah, dan MUI)
}

\author{
AD Kusumaningtyas \\ STAI DR KHEZ Muttaqien, Purwakarta
}

nining_ade@yahoo.com

Kata Kunci:
COVID-19, Social
Distancing,
sikap resmi
organisasi,
Fatwa,
Tokoh Agama

\begin{abstract}
Abstraksi
Pandemi COVID-19 sangat berpengaruh terhadap kebidupan keseharian masyarakat. Sejak awal pemerintab menyatakan pandemi ini sebagai Kejadian Luar Biasa (KLB) bencana non alam sejak. Maret 2020 yang lalu, berbagai kebiasaan masyarakat berubah. Seruan stay at home dalam bentuk bekerja dari rumah, belajar dari rumah, dan beribadah di rumah yang disampaikan oleh Presiden Joko Widodo maupun upaya social distancing (jaga jarak) yang diperkenalkan oleh WHO membawa dampak pada kehidupan keseharian masyarakat. Tak terkecuali kehidupan sosial keagamaan, termasuk tatacara pelaksanaan ibadah bagi muslim. Menyikapi hal ini, berbagai ormas keagamaan Islam dalam hal ini NU, Muhammadiyah, dan Majelis Ulama Indonesia mengeluarkan sikap resmi organisasi untuk menjawab pertanyaan umat tentang hal ini. Sejumlah surat edaran, instruksi, hasil bahtsul masa'il, maklumat, maupun fatwa terkait atas respon terhadap situasi pandemi COVID-19 diterbitkan. Hal ini merupakan salah satu bentuk komunikasi publik yang dilakukan oleh ormas-ormas tersebut, di samping seruan dan himbauan yang disampaikan oleh para tokoh agama. Studi ini hendak menelah sikap resmi keagamaan yang dilakukan oleh ketiga organisasi keagaman Islam tersebut maupun komunikasi publik yang dilakukan oleh para tokoh agama dari ketiga lembaga ini dalam menyampaikan pesan pencegahan penularan virus COVID-19 kepada umatnya.

Copyright (C) 2021 (AD Kusumaningtyas) DOI: https://doi.org/10.52593/mtq.02.1.02 Naskah diterima: 22 November 2020, direvisi: 4 Januari 2021, disetujui: 16 Januari 2021
\end{abstract}

\section{A. Pendahuluan}

Persoalan 'wabah virus corona' yang dikenal dengan nama resmi pandemik "Corona Virus Diseases 2019" atau COVID-19 telah menghadirkan persoalan di skala global. Hingga saat ini, pandemik COVID-19 ini telah menjangkiti lebih dari 200 negara di dunia, termasuk Indonesia. Namun sepertinya, sense of crisis seperti ini belum banyak dipahami oleh masyarakat. Oleh karenanya, Kementerian Agama RI telah menerbitkan panduan tentang tata cara cara pelaksanaan ibadah bagi umat Islam. Utamanya menyeru agar kegiatan shalat Jum'at dihentikan sementara waktu dan menggantikannya dengan shalat di rumah, menyusul seruan pemerintah yang disampaikan oleh Presiden RI kepada masyarakat untuk "belajar di rumah, bekerja di rumah, dan beribadah di rumah" atau yang dikenal oleh masyarakat dengan istilah stay at home untuk menghindari berkumpulnya massa dalam jumlah besar sebagai ikhtiar untuk mencegah penularan virus ini.

Sikap 'abai' terhadap protokol kesehatan dan seruan pemerintah ini, nampak dari beberapa kejadian yang sempat direkam dalam pemberitaan media massa. Di Gowa, Sulawesi 
Selatan sempat hampir diselenggarakan kegiatan Ijtima' Ulama Dunia Zona Asia 2020 pada jelang akhir Maret 2020 yang dihadiri oleh sekitar 8 ribu jama'ah tabligh dari berbagai negara di dunia dan akhirnya terpaksa dibubarkan oleh Kepolisian dan Pemerintah Daerah setempat ${ }^{1}$ Beberapa pemberitaaan setelahnya di beberapa media lokal dari berbagai daerah menyatakan bahwa banyak di antara peserta yang hadir ini terpapar virus COVID-19 dan terkonfirmasi sebagai kasus positif; bahkan beberapa dari mereka kini telah meninggal dunia. Selain itu, 170 jamaah salah satu masjid Jami’ di Tamansari, Kebon Jeruk Jakarta Barat terpaksa diisolasi setelah 3 jama'ah shalat Jumat yang diselenggarakan di masjid tersebut. ${ }^{2}$

Kompleksitas pandangan masyarakat terhadap sikap resmi ormas keagamaan dan komunikasi publik yang dibangun oleh tokoh agama dan tokoh masyarakat, dapat menjadi faktor pendukung maupun faktor penghambat sebuah pesan tersampaikan.(Effendi, 2020) Sekedar untuk menyebutkan beberapa contoh, beberapa waktu yang lalu, Masjid Salman ITB menerapkan jaga jarak dalam pengaturan shaf saat Shalat di masjid untuk mengantisipasi penularan virus corona. ${ }^{3}$ Ustadz Adi Hidayat, menyerukan agar umat cukup mengerjakan shalat berjamaah di rumah ${ }^{4}$ Aa Gym menyerukan agar warga tetap melaksanakan social distancing dan tetap di rumah, dengan cara mendatangi langsung kawasan pemukiman warga dan menyerukan himbauannya lewat pengeras suara ${ }^{5}$ Beragam upaya semacam ini menjadi penting sehingga masyarakat memiliki kesadaran untuk menjaga kesehatan diri dan keluarganya. State of The Art (SOTA) atau hal yang menyangkut kebaruan atau novelty dalam penelitian ini adalah masih terbatasnya penelitian bidang sosial terutama komunikasi terkait dengan isu COVID-19.

Kebanyakan penelitian yang ada, lebih merupakan penelitian ilmiah bidang eksakta terutama kedokteran untuk menemukan jenis virus, anti virus maupun obatnya. Namun, di antara beberapa penelitian yang ada dan membahas tema senada adalah: a)Penelitian Kominfo yang menemukan 25 Hoaks tentang Virus Corona, yang pemberitaan mengenai hal ini ditulis oleh Hari Widowati 31/1/2020 dengan judul, Kominfo Temukan 25 Hoaks tentang Korona ${ }^{6}$. 2)Tulisan Gun Gun Heryanto, Direktur The Political Literacy Institute dan Dosen Komunikasi Politik UIN Jakarta, Komunikasi Wabah Korona ${ }^{7}$, dan 3)Tulisan Olivia Hernanda,

\footnotetext{
${ }^{1}$ Pebriansyah Ariefana, Ijtima Ulama Asia di Gowa Batal, MUI: Untuk. Kepentingan Norma Agama, Kamis, 19 Maret 2020, pada suara.com; sebagaimana dikip dari situs https://www.suara.com/news/2020/03/19/105318/ ijtima-ulama-asia-di-gowa-batal-mui-untuk-kepentingan-norma-agama

${ }^{2}$ Lihat berita yang ditulis oleh Bonfilio Mahendra Wahanaputra Ladjar (Sandro Gatra, ed.), Tiga Jemaah Positif Covid-19, Sekitar 170 Orang Diisolasi di Masjid di Taman Sari, sebagaimana ditayangkan di Kompas.com, 27 Maret 2020. Pemberitaan ini juga bisa dibaca di: https://megapolitan.kompas.com/read/2020/03/27/22403151/tiga-jemaah-positif-covid-19-sekitar-170orang-diisolasi-di-masjid-di?page $=$ all.

${ }^{3}$ Republika, 17/3/2020

${ }^{4}$ Okezone.com, 30/3/2020

${ }^{5}$ Dara, 24/3/2020

6 Hari Widowati, Kominfo Temukan 25 Hoaks tentang Korona, 31/1/2020 yang dapat diakses melalui www.katadata.co.id

7 Gun Gun Heryanto, Komunikasi Wabah Corona, artikel pada Republika, 23/03/2020

22 | Jurnal Muttaqien: e-ISSN : 2723-5963
} 
Menimbang Peran Media dalam Menghadapi Epidemi'. Tulisan ini menyoroti minimnya perhatian media pada isu-isu kesehatan, serta mendorong pentingnya peran media untuk terus menekan pemerintah melakukan upaya-upaya optimal dalam deteksi, pemantauan, dan manjemen penanganan kasus secara keseluruhan.

Sementara itu, dalam perjalanan penelitian ini dilakukan dan penulisan laporan mulai dilakukan, penulis menemukan beberapa penelitian yang memiliki tema senada terkait dengan penelitian ini dan memiliki bahasan terkait dengan ormas keagamaan Islam dan Respon terhadap Pandemi COVID-19. Beberapa informasi ini penulis anggap cukup relevan untuk menjelaskan topik yang diangkat. Penelitian Dadan Suherdiana dkk.. misalnya , menyebutkan bahwa hasil penelitiannya menemukan bahwa bentuk pesan dakwah yang disampaikannya ormas Islam lebih banyak berkaitan tentang berita kegiatan menghadapi masa pandemi, berita opini, opini dan panduan organisasi menghadapi wabah seperti fatwa, imbauan, dan surat edaran,. Sedangkan Isi pesan dakwah banyak berkaitan dengan kegiatan muamalah, juga ibadah dan aqidah". Sementara itu Muhtada menyatatakan bahwa ada 2 alasan mengapa ormas keagamaan menjadi mitra pemerintah dalam mitigasi bencana sehingga diperlukan kerjasama dengan mereka. Pertama, ormas-ormas keagamaan, terutama yang besar seperti NU dan Muhammadiyah memiliki otoritas yang kuat untuk meluruskan pemahaman keagamaan yang keliru soal penanggulangan bencana. Para tokoh agama dari ormas tersebut, baik yang struktural maupun kultural, bisa memperbaiki paham keagamaan yang fatalistis dalam menyikapi wabah COVID-19. Kedua, tidak hanya otoritas keagamaan, ormas-ormas tersebut juga memiliki struktur bertingkat, dari tingkat ranting hingga pusat, yang tersebar di seluruh Nusantara. Struktur bertingkat dengan jaringan nasional ini sangat potensial untuk disinergikan dalam upaya mitigasi bencana. Selain itu, ormas-ormas ini juga memiliki badanbadan otonom, yang bekerja secara mandiri untuk mendukung tugas dan fungsi organisasi payungnya. $^{10}$

Di samping ormas keagaaman seperti NU dan Muhammadiyah, yang tak kalah penting adalah peran MUI. Dalam penelitiannya, Agus Mushodiq dan Ali Imron menyebutkan bahwa MUI merupakan aktor dari tindakan sosial keagamaan yang mengharapkan masyarakat muslim Indonesia terpengaruh dengan anjuran-anjuran model ibadah saat Pandemi COVID19 melalui fatwa yang diterbitkan. Motif tindakan sosial keagamaan MUI melalui fatwa yang diterbitkan mengandung tiga motif dominan, yaitu instrumentally rational, value rational, dan traditional. Dalam aspek motif instrumentally rational dalam fatwa mengacu pada berbagai macam model peribadatan yang dianggap paling masuk akal dipraktikkan untuk memutus rantai penyebaran COVID-19 dan mewujudkan daruratu khams. Adapun dari segi motif value rational, MUI menggunakan nilai-nilai dari Agama Islam yang bersumber dari Alquran, Hadis, dan Kaidah Fikih yang bersifat rasional-dinamis dan sarat akan probabilitas sehingga

8 Olivia Hernanda, , Menimbang Peran Media dalam Menghadapi Epidemii, pada rubrik Amatan, yang diterbitkan oleh Remotivi pada 3/3/2020 yang dapat diakses pada www.remotivi.id

9 Dadan Suherdiana*, Aang Ridwan, Uwes Fatoni, Rojudin berjudul Pesan Dakwah Ormas Islam Indonesia dalam Menghadapi Krisis Keagamaan Masa Pandemi Covid-19, pada Program Studi Komunikasi dan Penyiaran Islam, UIN Sunan Gunung Djati Bandung), 2020

10 Dani Muhtada, Agama dan Mitigasi Wabah COVID-19 (CSIS Commentaries, DMRU-011, 23 Maret 2020). Jurnal Muttaqien: e-ISSN : 2723-5963| 23 
melahirkan alternatif-alternatif peribadatan yang dapat dijadikan sebagai mitigasi wabah COVID-19. Dari segi motif tradisional, MUI berupaya untuk meneruskan tradisi para nabi dan sahabat ketika menghadapi wabah (thaa-un), sehingga model peribadatan yang mereka anjurkan merupakan upaya meneruskan tradisi sebelumnya dengan pendekatan hermeneutis. ${ }^{11}$

Penelitian ini sendiri memiliki beberapa tujuan. Yaitu untuk: 1)Memahami strategi komunikasi publik dari 3 organisasi keagamaan Islam yaitu Nahdlatul Ulama, Muhammadiyah, dan MUI terkait social distancing sebagai upaya pencegahan penularan COVID-19. 2) Mengidentifikasi pesan-pesan utama yang disajikan dalam sikap resmi organisasi dari Nahdlatul Ulama, Muhammadiyah, dan MUI terkait social distancing sebagai upaya pencegahan penularan COVID-19.dan 3)Menemukan adaptabilitas (kemampuan menyesuaikan diri dengan keadaan) dan inisiatif-inisiatif masyarakat akan bentuk kegiatan sosial keagamaan atau dakwah dari ketiga organisasi keagamaan Islam tersebut sebagai upaya mencegah dan mengatasi wabah atau pandemi COVID-19.

\section{B. Metode Penelitian/Metode Kajian}

Penelitian ini dilakukan dengan pendekatan kualitatif, dengan menggunakan analisis wacana (discourse analysis); dan lebih tepatnya pada analisis isi kualitatif (content analysis) atas produk sikap resmi 3 (tiga) ormas keagamaan Islam terkait dengan pencegahan penularan COVID-19.

Adapun alur kegiatan yang peneliti lakukan adalah dengan: a) Penelusuran informasi awal terhadap topik yang hendak diangkat, dengan melakukan analisis tematik terkait isi berita seputar COVID-19. b) Menggali sikap resmi organisasi melalui website ormas keagamaan tersebut maupun produk resmi kebijakan seperti Surat Edaran atau Maklumat yang diterbitkan oleh organisasi-organisasi tersebut. c) Melakukan telaah dengan menggunakan analisis tabel atas tema-tema yang diangkat, dan mengidentifikasi bentuk-bentuk kebijakan yang diambil. d) Melakukan komparasi atas produk kebijakan atau sikap resmi ketiga organisasi tersebut. e) Menggali pemberitaan terkait dengan upaya yang dilakukan oleh jajaran tokoh agama atau struktur di ketiga ormas keagamaan tersebut maupun kegiatan dalam jajaran organisasi di bawahnya. f) Membuat kesimpulan dan rekomendasi.

Penelitian ini dilakukan secara simultan, dengan memfokuskan penggalian data dalam 3 bulan antara Maret-Mei 2020 dimana pada ketiga bulan ini dinyatakan sebagai masa kritis sejak ditetapkannya pandemi COVID-19 dan perkiraan peningkatan jumlah kasus serta beragam upaya pencegahannya. Implementasi di masyarakat, akan terlihat dalam pemberitaan di masa 3 bulan ini. Selain itu, studi terkait dengan implementasinya di lapangan tidak terlalu urgen untuk dilakukan, mengingat pembahasan utamanya adalah "sikap resmi organisasi" sebagai pesan utama yang disampaikan. Dan bagaimana aktivitas publik pada ketiga organisasi tersebut dipandang sebagai respon atas pesan yang disampaikan oleh organisasi.

11 Muhamad Agus Mushodiq dan Ali Imron Peran Majelis Ulama Indonesia Dalam Mitigasi Pandemi Covid-19 (Tinjauan Tindakan Sosial dan Dominasi Kekuasaan Max Weber) yang diterbitkan oleh SALAM; Jurnal Sosial \& Budaya Syar-i FSH UIN Syarif Hidayatullah Jakarta Vol. 7 No. 5 (2020)

24 | Jurnal Muttaqien: e-ISSN : 2723-5963 


\section{Hasil dan Pembahasan (Research Findings)}

Penelitian ini dilakukan dengan pendekatan kualitatif, dengan menggunakan analisis wacana (discourse analysis); dan lebih tepatnya pada analisis isi kualitatif (content analysis) atas produk sikap resmi 3 (tiga) ormas keagamaan Islam terkait dengan pencegahan penularan COVID-19.

Adapun alur kegiatan yang peneliti lakukan adalah dengan :

- Penelusuran informasi awal terhadap topik yang hendak diangkat, dengan melakukan analisis tematik terkait isi berita seputar COVID-19.

- Menggali sikap resmi organisasi melalui website ormas keagamaan tersebut maupun produk resmi kebijakan seperti Surat Edaran atau Maklumat yang diterbitkan oleh organisasi-organisasi tersebut.

- Melakukan telaah dengan menggunakan analisis tabel atas tema-tema yang diangkat, dan mengidentifikasi bentuk-bentuk kebijakan yang diambil.

- Melakukan komparasi atas produk kebijakan atau sikap resmi ketiga organisasi tersebut.

- Menggali pemberitaan terkait dengan upaya yang dilakukan oleh jajaran tokoh agama atau struktur di ketiga ormas keagamaan tersebut maupun kegiatan dalam jajaran organisasi di bawahnya.

- Membuat kesimpulan dan rekomendasi

Penelitian ini dilakukan secara simultan, dengan memfokuskan penggalian data dalam 3 bulan antara Maret-Mei 2020 dimana pada ketiga bulan ini dinyatakan sebagai masa kritis sejak ditetapkannya pandemi COVID-19 dan perkiraan peningkatan jumlah kasus serta beragam upaya pencegahannya. Implementasi di masyarakat, akan terlihat dalam pemberitaan di masa 3 bulan ini. Selain itu, studi terkait dengan implementasinya di lapangan tidak terlalu urgen untuk dilakukan, mengingat pembahasan utamanya adalah "sikap resmi organisasi" sebagai pesan utama yang disampaikan. Dan bagaimana aktivitas publik pada ketiga organisasi tersebut dipandang sebagai respon atas pesan yang disampaikan oleh organisasi.

\section{Analisis Hasil Penelitian}

\section{Pandangan NU, Muhammadiyah, dan MUI terkait Pandemi COVID-19}

Munculnya virus Corona di Indonesia, mendapatkan tanggapan yang beragam dari masyarakat..Ada yang menanggapi dengan melakukan isolasi diri dan mempersiapkannya dengan baik, ada yang menanggapinya dengan acuh tak acuh, ada masyarakat yang menganggapnya sebagai adzab yang ditimpahkan kepada orang-orang dzalim, ada yang mengatakan bahwa corona adalah salah satu tentara Allah dan lain sebagainya. Ada yang bersikap teodisi atau fatalism dengan pasrah kepada keadaan. ${ }^{12}$ Oleh karenanya, bagaimana ketiga ormas keagamaan Islam ini memandang COVID-19 menjadi telaah tersendiri.

12 Lihat tulisan Muhamad Agus Mushodiq dan Ali Imron Peran Majelis Ulama Indonesia Dalam Mitigasi Pandemi Covid-19 (Tinjauan Tindakan Sosial dan Dominasi Kekuasaan Max Weber) yng diterbitkan oleh SALAM; Jurnal Sosial \& Budaya Syar-i FSH UIN Syarif Hidayatullah Jakarta Vol. 7 No. 5 (2020) 
Nahdlatul Ulama misalnya, memandang bahwa wabah COVID-19 adalah musibah dan bencana tersebut perlu direspon dengan menerbitkan Protokol NU Peduli COVID-19. ${ }^{13}$ Sementara itu, LBM PB NU menyatakan bahwa Covid-19 merupakan wabah (tho'un), karena itu orang yang meninggal akibat COVID-19 statusnya adalah syabid fil akbiroh. ${ }^{14}$

Sementara itu Muhammadiyah memandang bahwa : 1) wabah Covid-19 adalah salah satu musibah yang merupakan ujian dari Allah atas dasar sifat Rabman dan Rabim Allah, sehingga umat Islam harus menghadapinya dengan sabar, tawakal, dan ikhtiar. 2) Oleh karena itu pasien COVID-19 meninggal dunia yang sebelumnya telah berikhtiar dengan penuh keimanan untuk mencegah dan atau mengobatinya, maka mendapat pahala seperti pahala orang mati syahid.3)Usaha aktif mencegah penularan Covid-19 merupakan bentuk ibadah yang bernilai jihad, dan sebaliknya tindakan sengaja yang membawa pada risiko penularan merupakan tindakan buruk/zalim. 4) Upaya pengobatan sebagai bentuk ikhtiar wajib dilakukan. Oleh sebab itu, para ahli termasuk dalam hal ini pemerintah wajib menyelenggarakan upaya tersebut sekaligus menyediakan segala keperluan yang berkaitan dengannya. 5) Dalam rangka menghindari dampak buruk berkembangnya COVID-19 harus diperhatikan berbagai petunjuk dan protokol yang telah ditentukan oleh pihak berwenang, termasuk melakukan perenggangan sosial (at-tabā' ud al-ijtima' 'i $i$ social distancing) maupun upaya stay at home atau work from home sebagai tindakan preventif, dengan tetap memperhatikan produktifitas kerja. ${ }^{15}$

Sementara itu Majelis Ulama Indonesia (MUI) memandang bahwa COVID-19 adalah coronavirus desease, penyakit menular yang disebabkan oleh coronavirus yang ditemukan pada tahun 2019. ${ }^{16}$ Dalam Fatwa lainnya tentang Pengurusan Jenazah, dalam pertimbangannya MUI menyatakan: a) bahwa COVID-19 termasuk jenis penyakit berbahaya dan dapat menular kepada yang melakukan kontak dengan orang yang terpapar COVID-19 atau cara penularan lainnya; b) bahwa ketika pasien COVID-19 meninggal, maka virusnya masih ada di tubuhnya dan berbahaya yang dapat menular kepada orang yang melakukan kontak dengan jenazah tersebut dalam proses pengurusannya; c) bahwa muncul pertanyaan tentang tata cara pengurusan jenazah muslim pasien COVID-19 yang meliputi memandikan, mengafani, menyalatkan, dan mengebumikan sebagaimana aturan syariat terhadap jenazah

${ }^{13}$ Lihat Instruksi PB NU tentang Protokol NU Peduli COVID 19, dikeluarkan pada 12 Maret 2020/17 Rajab 1441 H, ditandatangani oleh Ketua Umum Prof.Dr. Said Agil Siraj dan Sekretaris Jenderal Dr.Ir.H.A Helmy Faisal Zaini dan Pejabat Rais Aam KH Miftahul Ahyar dan Katib Aam KH Yahya Kholil Staquf

${ }^{14}$ Lihat Hasil Babtsul Masail PB NU tentang Fiqh Pemulasaraan Jenazah Pasien COVID-19, tertanggal 21 Maret 2020, ditandatangani oleh Ketua LBM PB NU KHM Najib Hassan dan Sekretaris LBM PB NU Sarmidi Husna, MA.

${ }^{15}$ Lihat Edaran Pimpinan Pusat Muhammadiyah No. 03/EDR/I.0/E/2020 tentang Tuntunan Ibadah dalam Kondisi Darurat COVID-19 tertanggal 7 Sya'ban 1441H/31 Maret 2020 dan ditandatangani olehtertanggal dan ditandatangani oleh Ketum PP Muhammadiyah Haedar Nashir dan Sekretaris PP Muhammadiyah Agung Danarto

${ }^{16}$ Lihat dalam Fatwa Majelis Ulama Indonesia Nomor: 14 Tahun 2020 Tentang Penyelenggaraan Ibadah dalam Situasi Wabah COVID-19, pada Ketentuan Umum bagian pertama.

26 | Jurnal Muttaqien: e-ISSN : 2723-5963 
pada umumnya; d) bahwa oleh karena itu dipandang perlu menetapkan fatwa tentang Pedoman Pengurusan Jenazah (Tajbiz, al-Jana'iz) Muslim yang Terinfeksi COVID-19. ${ }^{17}$

Upaya untuk pencegahan terhadap penularan wabah menjadi concern ketiga ormas keagamaan ini. MUI Misalnya, mengutip hadits Nabi Muhammad saw. untuk tidak keluar dari satu area ke area lain yang terkena atau tidak keluar satu area yang sudah terkena wabah, dalam salah satu consideran fatwanya. Disebutkan hadits Nabi Muhammad saw. yang artinya, "Dari Nabi saw sesunggubnya beliau bersabda: "Iika kamu mendengar wabab di suatu wilayah, maka janganlah kalian memasukinya. Tapi jika terjadi wabah di tempat kamu berada, maka jangan tinggalkan tempat itu." (HR. al-Bukhari). Pada hadits lainnya dinyatakan, "Sesunggubnya Umar sedang dalam perjalanan menuju Syam, saat sampai di wilayah bernama Sargh. Saat itu Umar mendapat kabar adanya wabah di wilayah Syam. Abdurrahman bin Auf kemudian mengatakan pada Umar jika Nabi Muhammad saw pernah berkata, "Jika kamu mendengar wabah di suatu wilayah, maka janganlah kalian memasukinya. Tapi jika terjadi wabah di tempat kamu berada, maka jangan tinggalkan tempat itu." (HR. al-Bukhari). ${ }^{18}$ Sementara itu Muhammadiyah menyebutkan dalam Surat Maklumat yang dikeluarkan oleh PP Muhammadiyah yang menyerukan agar warga Muhammadiyah membatasi bepergian ke tempat dan kegiatan yang beresiko penularan COVID-19 sesuai dengan hadits Nabi yang artinya, "Rasulullah $S A W$. bersabda,"tha'un (wabah penyakit menular) adalah suatu peringatan dari Allah SWT untuk menguji hamba-hamba-Nya dari kalangan manusia. Maka bila kamu mendengar penyakit itu di suatu negeri, janganlab kamu masuk ke negeri itu. Dan apabila wabah itu berjangkit di tempat kamu berada, jangan pula kamu lari dari padanya." (HR. Bukhari dan Muslim dari Usamah bin Zaid). ${ }^{19}$ Sementara itu, PB NU merespon hal ini dengan mengedarkan Instruksi tentang Protokol NU Peduli COVID-19, dimana pada salah satu protokol umumnya mengajak masyarakat untuk banyak membaca do'a untuk dijauhkan

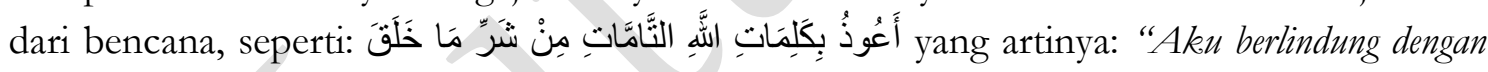
kalimat-kalimat Allah yang sempurna dari kejahatan makbluk yang diciptakan-Nya" dan

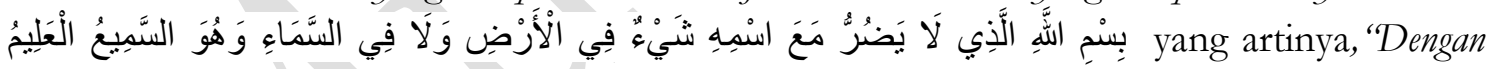
menyebut asma Allah yang dengan nama-Nya tidak akan bisa membahayakan apa pun yang ada di bumi dan yang ada di langit. Dia Maha Mendengar lagi Maha Mengetabui. „20

\section{Isu-isu Social Distancing terkait Peribadatan: Respon NU, Muhammadiyah dan MUI}

Terkait dengan isu COVID -19 secara umum PB NU menanggapinya melalui respon yang tercantum dalam Instruksi tentang Protokol NU Peduli COVID-19, yang secara umum sebenarnya berisi tentang Pembiasaan Hidup Bersih dan Sehat (PHBS). Sementara, terkait social distancing sendiri secara eksplisit baru muncul dalam protokol di area lembaga

\footnotetext{
${ }^{17}$ Lihat dalam Fatwa Majelis Ulama Indonesia Nomor: Nomor: 18 Tahun 2020 Tentang Pedoman Pengurusan Jenazah (Tajhiz al-Janaiz) Muslim yang Terinfeksi COVID-19

18 Fatwa Majelis Ulama Indonesia Nomor: 14 Tahun 2020 Tentang Penyelenggaraan Ibadah dalam Situasi Wabah COVID-19., pada poin MENGINGAT

${ }^{19}$ Lihat dalam Surat Maklumat Pimpinan Pusat Muhammadiyah, No.02/MLM/I.0/H/2020 tentang Wabah Corona Virus Disease

${ }^{20}$ Lihat dalam Instruksi PB NU tentang Protokol NU Peduli COVID 19, 12 Maret 2020
} 
pendidikan termasuk pesantren, pada poin no. 12 hingga 14. Bunyi protokol tersebut adalah: (12) Menginstruksikan kepada warga pesantren untuk menghindari kontak fisik langsung (bersalaman, cium tangan, dsb.), dan menggantikannya dengan bentuk, penghormatan lain selama wabah terjadi. (13) Menunda kegiatan banyak orang yang mengumpulkan banyak orang atau kegiatan di luar lingkungan pesantren (kemah, studi wisata). (14) Jika belum ada kasus konfirmasi di lingkungan pesantren, maka pesantren boleh memulangkan santri. Sebaliknya, jika ada kasus konfirmasi, maka seluruh warga pesantren tidak boleh meninggalkan pesantren selama masa observasi 14 hari. ${ }^{21}$ Secara lebih detail, Rabithah Ma'ahid al-Islamiyah (RMI) sebagai asosiasi pesantren di lingkungan Nahdlatul Ulama menurunkan kebijakan dalam hal ini melalui Surat Edarannya tentang Protokol Pencegahan Penyebaran Corona Virus Disease (COVID-19) pada Pondok Pesantren. ${ }^{22}$ Dalam protokol terkait dengan Individu dan Keluarga PB NU juga melarang warga bepergian ke daerah ramai atau daerah rawan COVID-19. ${ }^{23}$

Sementara itu, Muhammadiyah, terkait dengan social distancing ini juga menyampaikan maklumat yang isinya antara lain: 1)Kegiatan-kegiatan yang bersifat pengumpulan massa pengajian, seminar, kegiatan sosial dan lain-lain agar ditunda pelaksanaannya atau diselenggarakan dengan cara yang lebih terbatas atau menggunakan teknologi informasi. 2) Kegiatan ibadah seperti shalat berjamaah dan shalat Jum'at di Masjid dapat dilaksanakan dengan ketentuan sbb,: a)bagi yang sakit disarankan untuk shalat di rumah, b)Apabila dipandangdarurat pelaksanaan shalat Jum'at dapat diganti dengan shalat Dhuhur di rumah, dan pelaksanaannya bisa dilakukan secara berjamaah di rumah. 3)Kegiatan pendidikan di lingkungan Muhammadiyah dan Aisyiah dilaksanakan menyesuaikan dengan kebijakan pemerintah pusat dan pemerintah daerah, dan dikoordinasikan dengan Majelis Pendidikan Dasar dan Menengah, dan Majelis Pendidikan Tinggi, Penelitian dan Pengembangan. 4)Amal usaha kesehatan agar mempersiapkan penanganan COVID-19 diselaraskan dengan Protokol Kementerian Kesehatan dalam Koordinasi Majelis Pembina Kesehatan Umum yang bersinergi dengan majelis, lembaga, organisasi otonom, dan amal usaha lain . PP Muhammadiyah juga telah membentuk Mubammadiyah COVID-19 Command Center (MCCC) yang bertugas mengkoordinasikan pelaksanaan program dan aksi penanganan COVID-19. Dan 5)Seruan kepada warga Muhammadiyah untuk: -meningkatkan kebiasaan dan pola hidup sehat dan menjaga kebersihan pribadi dan lingkungan, serta mengikuti protokol pencegahan COVID-19 yang dikeluarkan oleh pemerintah, dan 6) membatasi bepergian yang beresiko penularan COVID-19. ${ }^{24}$

Adapun Majelis Ulama Indonesia (MUI) merespon soal pencegahan penularan COVID-19 dan social distancing ini pada Ketentuan Umum no. 1 dan 2 yang menyatakan:

${ }^{21}$ Lihat dalam Instruksi PB NU tentang Protokol NU Peduli COVID 19, 12 Maret 2020

${ }^{22}$ Lihat Surat Edaran Nomor : 835/A/PPRMI/SE/III/2020TANGGAL : 13 Maret 2020 M / 18 Rajab 1441 $\mathrm{H}$ tentang Protokol Pencegahan Penyebaran CORONA VIRUS DISEASE 19 (COVID-19) pada Pondok Pesantren. Dikeluarkan oleh PP. Rabithah Ma'ahid Islamiyah (Asosiasi Pesantren Nahdhatul Ulama), ditandatangani oleh Ketua RMI H.Abdul Ghofarrozin dan Sekretaris RMI Habib Sholeh

23 Instruksi PB NU tentang Protokol NU Peduli COVID 19, 12 Maret 2020, terkait Protokol pada Individu dan Keluarga.

24 Surat Maklumat Pimpinan Pusat Muhammadiyah, No.02/MLM/I.0/H/2020 tentang Wabah Corona Virus Disease

28 | Jurnal Muttaqien: e-ISSN : 2723-5963 
Setiap orang wajib melakukan ikhtiar menjaga kesehatan dan menjauhi setiap hal yang dapat menyebabkan terpapar penyakit, karena hal itu merupakan bagian dari menjaga tujuan pokok beragama (al-Dharuriyat al-Khams). 2. Orang yang telah terpapar virus Corona, wajib menjaga dan mengisolasi diri agar tidak terjadi penularan kepada orang lain. Baginya shalat Jumat dapat diganti dengan shalat zuhur, karena shalat jumat merupakan ibadah wajib yang melibatkan banyak orang sehingga berpeluang terjadinya penularan virus secara massal. Baginya haram melakukan aktifitas ibadah sunnah yang membuka peluang terjadinya penularan, seperti jamaah shalat lima waktu/rawatib, shalat Tarawih dan Ied di masjid atau tempat umum lainnya, serta menghadiri pengajian umum dan tabligh akbar. ${ }^{25}$ MUI juga menyampaikan rekomendasinya bahwa pemerintah wajib melakukan pembatasan super ketat terhadap keluar-masuknya orang dan barang ke dan dari Indonesia kecuali petugas medis dan barang kebutuhan pokok serta keperluan emergency. ${ }^{26}$

Secara lebih spesifik, sikap ketiga ormas keagamaan Islam tersebut dapat dilihat dari sikap dan agenda-agenda mereka terkait dengan isu-isu di bawah ini. Yaitu:

\section{1) Penatalaksanaan Penyelenggaraan Kegiatan Ibadah}

Terkait dengan penatalaksanaan penyelenggaraan Ibadah selama Pandemi COVID-19, PB NU melalui Instruksinya tentang Protokol NU Peduli COVID-19 untuk Musholla dan tempat ibadah, disebutkan ketentuan antara lain: 1) Pastikan seluruh area umum masjid bersih dab bebas infeksi, yaitu dengan melakukan pembersihan area masjid dan penyemprotan disinfektan minimal 1 kali sehari mencakup lantai, dinding, pegangan pintu, microphone, mimbar, tempat wudhu, dan toilet. Masjid dianjurkantidak menggunakan karpet. Jamaah diharapkan membawa sajadah masing-masing atau alas sujud yang lain, seperti sapu tangan. Jika masih tetap menggunakan karpet, pengurusmasjid harus melakukan pembersihan karpet dengan menggunakan vacuum cleaner minimal 1 kali setiap hari. Sementara mukena, sarung, dan sajadah yang tersedia di masjid diharuskan diganti setiap hari. 2) Biasakan mencuci tangan dan menerapkan etika batuk/bersin, yaitu dengan menyediakan media informasi mengenai pentingnya cuci tangan dan cara cuci tangan yang benar. Sediakan juga media informasi terkait etika batuk/bersin. Lalu menyediakan sabun cair di setiap tempat wudhu, hand sanitizer di dalam masjid dan mengingatkan jama'ah untuk selalu mencuci tangan dengan sabun atau hand sanitizer sebelum memulai aktivitas. 3) Kegiatan ibadah di masjid: selama wabah COVID-19 dianjurkan tidak beribadah di masjid. 4) Berkoordinasi dengan call center Posko NU Peduli COVID19 dengan nomor hotline: 0813-8979-8679. ${ }^{27}$

Sementara itu, terkait dengan penyelengaraan ibadah selama Pandemi COVID19 ini Muhammadiyah telah mengaturnya dengan mengeluarkan Surat Edaran

${ }^{25}$ Fatwa Majelis Ulama Indonesia Nomor: 14 Tahun 2020 Tentang Penyelenggaraan Ibadah dalam Situasi Wabah COVID-19.

26 Fatwa Majelis Ulama Indonesia Nomor: 14 Tahun 2020 Tentang Penyelenggaraan Ibadah dalam Situasi Wabah COVID-19.

27 Instruksi PB NU tentang Protokol NU Peduli COVID 19, 12 Maret 2020, terkait Protokol pada Masjid dan Musholla. 
Pimpinan Pusat Muhammadiyah No. 03/EDR/I.0/E/2020 tentang Tuntunan Ibadah dalam Kondisi Darurat COVID-19 tertanggal 7 Sya'ban 1441H/31 Maret 2020 dan ditandatangani olehtertanggal dan ditandatangani oleh Ketum PP Muhammadiyah Haedar Nashir dan Sekretaris PP Muhammadiyah Agung Danarto. Dalam poin no.7 Surat ini dinyatakan, "Dalam kondisi tersebarnya Covid-19 seperti sekarang dan yang mengharuskan perenggangan sosial (at-tabā'ud alijtimā' $\bar{\imath}$ / social distancing), Shalat lima waktu dilaksanakan di rumah masing-masing dan tidak perlu dilaksanakan di masjid, musala, dan sejenisnya yang melibatkan konsentrasi banyak orang, agar terbindar dari mudarat penularan COVID-19.'28 Tidak didapatkan informasi tentang bagaimana penatalaksanaan penyelenggaraan ibadah selama pandemi COVID-19 ini. Menurut peneliti, hal ini mungkin sejalan dengan salah satu bunyi edaran bahwa selama pandemi ini, shalat lima waktu diselenggarakan di rumah masing-masing dan tidak perlu di masjid.

Adapun penatalaksanaan penyelenggaraan ibadah menurut MUI, disajikan dalam Fatwa MUI No. 14 tahun 2020, yang di antaranya memuat berbagai ketentuan hukum seperti berikut: 3) Orang yang sehat dan yang belum diketahui atau diyakini tidak terpapar COVID-19, harus memperhatikan hal-hal sebagai berikut: a. Dalam hal ia berada di suatu kawasan yang potensi penularannya tinggi atau sangat tinggi berdasarkan ketetapan pihak yang berwenang maka ia boleh meninggalkan Shalat Jumat dan menggantikannya dengan shalat zuhur di tempat kediaman, serta meninggalkan jamaah shalat lima waktu/rawatib, Tarawih, dan Ied di masjid atau tempat umum lainnya. b. Dalam hal ia berada di suatu kawasan yang potensi penularannya rendah berdasarkan ketetapan pihak yang berwenang maka ia tetap wajib menjalankan kewajiban ibadah sebagaimana biasa dan wajib menjaga diri agar tidak terpapar COVID-19, seperti tidak kontak fisik langsung (bersalaman, berpelukan, cium tangan), membawa sajadah sendiri, dan sering membasuh tangan dengan sabun. 4)Dalam kondisi penyebaran COVID-19 tidak terkendali di suatu kawasan yang mengancam jiwa, umat Islam tidak boleh menyelenggarakan shalat jumat di kawasan tersebut, sampai keadaan menjadi normal kembali dan wajib menggantikannya dengan shalat zuhur di tempat masing-masing. Demikian juga tidak boleh menyelenggarakan aktifitas ibadah yang melibatkan orang banyak dan diyakini dapat menjadi media penyebaran COVID-19, seperti jamaah shalat lima waktu/rawatib, shalat Tarawih dan Ied di masjid atau tempat umum lainnya, serta menghadiri pengajian umum dan majelis taklim. 5) Dalam kondisi penyebaran COVID-19 terkendali, umat Islam wajib menyelenggarakan shalat Jumat dan boleh menyelenggarakan aktifitas ibadah yang melibatkan orang banyak, seperti jamaah shalat lima waktu/rawatib, shalat Tarawih dan Ied di masjid atau tempat umum

28 Surat Edaran Pimpinan Pusat Muhammadiyah No. 03/EDR/I.0/E/2020 tentang Tuntunan Ibadab dalam Kondisi Darurat COVID-19 tertanggal 7 Sya'ban 1441H/31 Maret 2020 dan ditandatangani olehtertanggal dan ditandatangani oleh Ketum PP Muhammadiyah Prof. Dr. H. Haedar Nashir, MA dan Sekretaris PP Muhammadiyah Dr.H. Agung Danarto, MA

30 | Jurnal Muttaqien: e-ISSN : 2723-5963 
lainnya, serta menghadiri pengajian umum dan majelis taklim dengan tetap menjaga diri agar tidak terpapar COVID-19. ${ }^{29}$

\section{2) Penyelenggaraan Ibadah Shalat Berjamaah dan Shalat Jum'at}

Isu berikutnya yang cukup penting dibicarakan dan menjadi concern pada saat pandemi COVID-19 dinyatakan oleh pemerintah sebagai situasi darurat bencana non alam adalah soal pelaksanaan shalat berjama'ah dan shalat Jum'at. Dalam hal ini, tidak banyak ditemukan rumusan yang dikeluarkan oleh Nahdlatul Ulama, baik oleh PB NU maupun badan organisasi otonom (Banom)-nya. Mungkin hal ini telah tercakup dalam Instruksi nstruksi PB NU tentang Protokol NU Peduli COVID 19, 12 Maret 2020, terkait Protokol pada Masjid dan Musholla, pada poin ketiga yaitu 3) Kegiatan ibadah di masjid: selama wabah COVID-19 dianjurkan tidak beribadah di masjid. ${ }^{30}$

Sementara itu, sebagaimana telah dikemukan sebelumnya dalam hal penatalaksanaan penyelenggaraan ibadah, Muhammadiyah memiliki sikap sebagaimana yang tercantum pada poin 7 SE Muhammadiyah No. 03 tahun 2020, yang isinya: Dalam kondisi tersebarnya Covid-19 seperti sekarang dan yang mengharuskan perenggangan sosial (at-taba' $\bar{a}^{\prime}$ alijtima' $\bar{c} /$ / social distancing), Shalat lima waktu dilaksanakan di rumah masing-masing dan tidak perlu dilaksanakan di masjid, musala, dan sejenisnya yang melibatkan konsentrasi banyak orang, agar terhindar dari mudarat penularan COVID-19. Sementara itu, terkait dengan shalat Jum'at Muhammadiyah berpendapat bahwa Shalat Jumat diganti dengan Shalat Zuhur (empat rakaat) di rumah masing-masing. Hal ini didasarkan kepada keadaan masyaqqah dan juga didasarkan kepada ketentuan dalam hadis berikut bahwa Shalat Jumat adalah kewajiban pokok, dan mafhumnya Shalat Zuhur adalah kewajiban pengganti (Ini juga adalah kaul jadid Imam asy-Syāfi ‘̄i) : idza ta’arradha al-ashlu yushaaru ila al-badali (Apabila yang pokok tidak dapat dilaksanakan, maka beralih kepada pengganti [Syarh ManZümat al-Qawā'id al-Fiqhiyyah]. Berdasarkan kaidah ini, karena Shalat Jumat sebagai kewajiban pokok tidak dapat dilakukan, maka beralih kepada kewajiban pengganti, yaitu Shalat Zuhur empat rakaat yang dikerjakan di rumah masing-masing. Peralihan kepada kewajiban pengganti ini (Shalat Zuhur) dapat didasarkan kepada mafhüm aulā (argumentum a minore ad maius) dari hadis berikut. Mafbüm aulā (argumentum a minore ad maius) menyatakan bahwa apabila suatu hal (masyaqqah) yang lebih ringan dapat membenarkan tidak melakukan suatu yang wajib, maka hal (masyaqqah) yang lebih berat tentu lebih dapat lagi membenarkan tidak melakukan yang wajib itu. Hadits yang dimaksud artinya: Dari 'Abdullāh Ibn 'Abbās (diriwayatkan) bahwa ia mengatakan kepada muazinnya di suatu bari yang penuh bujan: Jika engkau sudah mengumandangkan asyhadu an là iläha illalläh (aku bersaksi bahwa tiada Tuban

${ }^{29}$ Fatwa Majelis Ulama Indonesia Nomor: 14 Tahun 2020 Tentang Penyelenggaraan Ibadab dalam Situasi Wabah COVID-19.

30 Instruksi PB NU tentang Protokol NU Peduli COVID-19, 12 Maret 2020, terkait Protokol pada Masjid dan Musholla 
selain Allah), asyhadu anna muhammadan rasülulläh (aku bersaksi bahwa Mubammad utusan Allab), maka jangan ucapkan hayya 'alaș-Șaläh (kemarilah untuk Shalat), namun ucapkan Șallü fi buyütikum (Shalatlah kalian di rumah masing-masing). Rawi melanjutkan: Seolabolah orang-orang pada waktu itu mengingkari hal tersebut. Lalu Ibn 'Abbäs mengatakan: Apakah kalian merasa aneh dengan ini? Sesunggubnya hal ini telah dilakukan oleh orang yang lebih baik dariku (maksudnya Rasulullah saw). Sesunggubnya Shalat Jumat itu adalab bal yang wajib ('azmab), namun aku tidak suka memberatkan kepada kalian sehingga kalian berjalan di jalan becek dan jalan licin [HR Muslim]. Dalam hadis ini suatu hal (masyaqqah) yang kecil, yaitu hujan yang tidak menimbulkan bahaya dan mudarat, hanya menyebabkan sedikit ketidaknyamanan, dapat menjadi alasan untuk tidak menghadiri Shalat Jumat, maka keadaan (masyaqqah) yang jauh lebih berat, seperti penyebaran Covid-19 seperti sekarang yang sangat berbahaya, tentu lebih dapat lagi untuk menjadi alasan tidak menghadiri Shalat Jumat. Bahkan penyelenggaraan Shalat Jumat ditiadakan dalam rangka menghindari bahaya tersebut. Menghindari mudarat lebih diutamakan dari mendatangkan maslahat, sesuai dengan kaidah dar'u al-mafasid muqaddamun min jalb almashalih (Menghindari kemudaratan lebih diutamakan dari mendatangkan maslahat [Al-Asybāh wa an-Nazā'ir oleh as-Sayūțī, h. 87; oleh Ibn Nujaim, h. 78]. Penggantian Shalat Jumat menjadi Shalat Zuhur bagi orang yang uzur juga didasarkan pada hadis panjang yang menceritakan tentang perjalanan haji wada' Nabi. Ketika itu Nabi berada di Arafah pada hari Jumat, dan beliau tidak melaksanakan Shalat Jumat, tetapi menjamak Shalat Zuhur dengan Ashar sebagaimana kutipan hadis berikut yang artinya, "Kemudian Nabi bangkit lalu melaksanakan Shalat Zubur, dan bangkit kembali untuk. melaksanakan Shalat Ashar. Di antara dua Shalat itu, Nabi tidak melaksanakan Shalat yang lain [Lihat selengkeapnya pada HR Muslim no. 1218]. ${ }^{31}$

Secara umum MUI memberikan tuntunan dalam ketentuan hukum dalam fatwanya sebagaimana disebut dalam poin 2) Orang yang telah terpapar virus Corona, wajib menjaga dan mengisolasi diri agar tidak terjadi penularan kepada orang lain. Baginya shalat Jumat dapat diganti dengan shalat zuhur, karena shalat jumat merupakan ibadah wajib yang melibatkan banyak orang sehingga berpeluang terjadinya penularan virus secara massal. Baginya haram melakukan aktifitas ibadah sunnah yang membuka peluang terjadinya penularan, seperti jamaah shalat lima waktu/rawatib, shalat Tarawih dan Ied di masjid atau tempat umum lainnya, serta menghadiri pengajian umum dan tabligh akbar. Dan 3) Orang yang sehat dan yang belum diketahui atau diyakini tidak terpapar COVID-19, harus memperhatikan halhal sebagai berikut: a) Dalam hal ia berada di suatu kawasan yang potensi penularannya tinggi atau sangat tinggi berdasarkan ketetapan pihak yang berwenang maka ia boleh meninggalkan Shalat Jumat dan menggantikannya dengan shalat zuhur

${ }^{31}$ Lihat Surat Edaran Pimpinan Pusat Muhammadiyah No. 03/EDR/I.0/E/2020 tentang Tuntunan Ibadah dalam Kondisi Darurat COVID-19 tertanggal 7 Sya'ban 1441H/31 Maret 2020 dan ditandatangani olehtertanggal dan ditandatangani oleh Ketum PP Muhammadiyah Haedar Nashir dan Sekretaris PP Muhammadiyah Agung Danarto

32 | Jurnal Muttaqien: e-ISSN : 2723-5963 
di tempat kediaman, serta meninggalkan jamaah shalat lima waktu/rawatib, Tarawih, dan Ied di masjid atau tempat umum lainnya. ${ }^{32}$

Secara lebih detail, MUI juga menerbitkan Fatwa Majelis Ulama Indonesia Nomor. 31 Tahun 2020 tentang Penyelenggaraan Shalat Jum'at dan Jama'ah untuk mencegah penularan wabah COVID-19. Dua di antara pertimbangan MUI menerbitkan fatwa ini adalah a) bahwa terkait pelonggaran aktifitas sosial seiring mulai meredanya ancaman wabah COVID-19 di beberapa kawasan, maka banyak dari pengurus Dewan Kemakmuran Masjid (DKM) akan membuka kembali masjid untuk diselenggarakan kembali shalat Jum'at dan shalat berjamaah lima waktu (rawatib); b) bahwa wabah COVID-19 saat ini belum benar-benar hilang dari negeri ini, bahkan di berbagai negara terpaksa menerapkan kembali karantina sosial setelah meningkatnya kembali angka penyebaran; c) bahwa muncul pertanyaan di masyarakat tentang hukum pelaksanaan shalat Jum'at dan shalat jama'ah lima waktu dengan protokol kesehatan seperti dengan merenggangkan saf dalam rangka penerapan jaga jarak (physical distancing), shalat dengan menggunakan masker, dan tata cara pelaksanaan shalat Jum'at akibat physical distancing yang berdampak pengurangan daya tampung. Alasan-alasan tersebut membuat MUI menetapkan fatwa terkait dengan penyelenggaraan shalat jama'ah dan shalat Jum'at yang dilaksanakan dalam situasi. Akhirnya, ditetapkanlan Fatwa MUI yang diantaranya berisi ketentuan hukum penyelenggaraan shalat jama'ah dan shalat Jum'at yang isinya: A. Perenggangan Saf Saat Berjamaah 1) Meluruskan dan merapatkan saf (barisan) pada shalat berjamaah merupakan keutamaan dan kesempurnaan berjamaah. 2) Shalat berjamaah dengan safyang tidak lurus dan tidak rapat bukumnya tetap sah tetapi kehilangan keutamaan dan kesempurnaan jamaah. 3) Untuk mencegah penularan wabah COVID-19, penerapan physical distancing saat shalat jamaah dengan cara merenggangkan saf hukumnya boleh, shalatnya sah dan tidak kebilangan keutamaan berjamaah karena kondisi tersebut sebagai hajat syar'iyyah. B. Pelaksanaan Shalat Jum'at 1) Pada dasarnya shalat Jum'at hanya boleh diselenggarakan satu kali di satu masjid pada satu kawasan. 2)Untuk mencegah penularan wabah COVID-19 maka penyelenggaraan shalat Jumat boleh menerapkan physical distancing dengan cara perenggangan saf. 3) Jika jamaah shalat Jum'at tidak dapat tertampung karena adanya penerapan physical distancing, maka boleh menyelenggarakan shalat Jum'at berbilang (ta'addud aljumu'ab), dengan menyelenggarakan shalat Jum'at di tempat lainnya seperti mushalla, aula, gedung pertemuan, gedung olahraga, dan stadion. 4) Dalam hal masjid dan tempat lain masib tidak menampung jamaah shalat Jum'at dan/atau tidak ada tempat lain untuk pelaksanaan shalat Jum'at, maka Sidang Komisi Fatwa MUI berbeda pendapat terhadap jamaah yang belum dapat melaksanakan shalat Jum'at sebagai berikut: a) Pendapat pertama, jamaah boleh menyelenggarakan shalat Jum'at di masjid atau tempat lain yang telah melaksanakan shalat Jum'at dengan model shift, dan pelaksanaan shalat Jum'at dengan model shift hukumnya sah. b)Pendapat kedua, jamaah melaksanakan shalat zubur, baik secara sendiri maupun berjamaah,

32 Fatwa Majelis Ulama Indonesia Nomor: 14 Tahun 2020 Tentang Penyelenggaraan Ibadah dalam Situasi Wabah COVID-19 
dan pelaksanaan shalat Jum'at dengan model shift hukumnya tidak sah. Terhadap perbedaan pendapat di atas (point a dan b), dalam pelaksanaannya jamaah dapat memilib salah satu di antara dua pendapat dengan mempertimbangkan keadaan dan kemaslahatan di wilayah masingmasing. ${ }^{33}$

\section{3) Penyelenggaran Shalat Idul Fitri}

Idul Fitri merupakan hari raya umat Islam. Oleh karenanya, hal ini tentu menjadi concern hampir seluruh ormas keagamaan Islam. Tak terkecuali NU, Muhammadiyah, dan MUI. Nahdlatul Ulama telah mengeluarkan sikap terkait penyelenggaraan shalat Idul Fitri melalui Hasil Bahtsul Masail Lembaga Babtsul Masail PB NU tentang Pelaksanaan Shalat Id di Rumah, tertanggal 2020. Hasil Bahtsul Masail ini ditandatangani oleh Ketua LBM PB NU KH M. Najib Hassan dan Sekretaris LBM PB NU Sarmidi Husna, MA. Hasil Bahstul Masail ini menyatakan antara lain shalat idul fitri adalah perkara sunnah atau maksimal fardhu kifayah. Sebab, yang wajib bagi umat Islam pada tanggal 1 Syawal itu bukan Shalat I'ed-nya melainkan tak berpuasanya. Menurut hasil pembahasan babtsul masail ini dari sudut fikih Islam ternyata dimungkinkan bagi umat Islam melaksanakan Shalat I'ed di rumah bersama keluarga atau sendirian. Sebab, berbeda dengan pelaksanaan shalat Jum'at yang dalam madzhab Syafi'i dipersyaratakan dilaksanakan secara berjamaah dengan minimal 40 orang, maka Shalat I'ed tak mempersyaratkan itu. Dengan demikian, Shalat I'ed--baik 'idul fitri maupun 'idul adha--boleh dilaksanakan di rumah, baik secara berjamaah bersama keluarga minimal dua orang maupun sendirian. LBM juga menyatakan bahwa sebagaimana Shalat I'ed itu sunnah, maka demikian juga khutbah id-nya; sunnah. Karena itu, sekiranya Shalat I'ed di rumah dilangsungkan secara berjamaah, maka disunnahkan setelah pelaksanaan Shalat I'ed dilanjutkan dengan penyampaian khutbah. Bahkan, jika dalam satu keluarga misalnya tidak ada yang cakap berkhutbah, maka Shalat I'ed tanpa khutbah 'id juga sah. Sebab, khutbah 'id bukan merupakan syarat sah pelaksanaan Shalat I'ed, tetapi hanya kesunnahan saja. ${ }^{34}$

Selanjutnya, pandangan fikih tentang kebolehan Shalat I'ed di rumah itu bisa menjadi pegangan hukum umat Islam terutama yang berada di zona kuning. Sebab, menurut para fuqaba', salah satu yang bisa dijadikan alasan (u'dær) untuk tidak melaksanaan shalat jamaah di masjid adalah adanya kekhawatiran (khauf) yang meliputi tiga hal yaitu kekhawatiran akan keselamatan jiwa, tercederainya kehormatan, dan kekhawatiran akan hilangnya harta benda. LBM juga menyatakan bahwa memperhatikan demikian berbahayanya virus ini, maka umat Islam yang berada di zona kuning pun dianjurkan mengambil dispensasi hukum (rukhshoh), yaitu memilih melaksanakan Shalat I'ed di rumah masing-masing daripada

${ }^{33}$ Lihat dalam Fatwa Majelis Ulama Indonesia Nomor. 31 Tahun 2020 tentang Penyelenggaraan Shalat Jum'at dan Jama'ah untuk. Mencegah Penularan Wabab COVID-19

${ }^{34}$ Lihat Hasil Babtsul Masail Lembaga Bahtsul Masail PB NU tentang Pelaksanaan Shalat Id di Rumah, tertanggal 20 Mei 2020. Hasil Bahtsul Masail ini ditandatangani oleh Ketua LBM PB NU KH M. Najib Hassan dan Sekretaris LBM PB NU Sarmidi Husna, MA.

34 | Jurnal Muttaqien: e-ISSN : 2723-5963 
melaksanakannya di masjid atau tanah lapang. Sementara di daerah yang sudah ditetapkan sebagai zona merah oleh pemerintah, haram hukumnya melaksanakan Shalat I'ed di masjid atau tanah lapang. Sebab, menghindari kerumunan banyak orang yang diduga kuat sebagai salah satu sarana penyebaran virus corona adalah wajib. Dan secara fiqhiyyah, menjaga diri agar tidak tertular virus tersebut merupakan perkara wajib yang harus diutamakan daripada menjalankan Shalat I'ed di masjid atau tanah lapang yang disunnahkan. ${ }^{35}$

Sikap Muhammadiyah terkait dengan penyelenggaraan shalat Idul Fitri, secara umum sudah tergambar dalam Surat Edaran Pimpinan Pusat Muhammadiyah No. 03/EDR/I.0/E/2020 tentang Tuntunan Ibadah dalam Kondisi Darurat COVID-19. Pada poin 12 huruf dinyatakan bahwa Shalat I'edulfitri adalah sunnah muakkadah dan merupakan syiar agama yang amat penting. Namun apabila pada awal Syawal $1441 \mathrm{H}$ mendatang tersebarnya COVID-19 belum mereda, Shalat I'edulfitri dan seluruh rangkaiannya (mudik, pawai takbir, halal bihalal, dan lain sebagainya) tidak perlu diselenggarakan. Tetapi apabila berdasarkan ketentuan pihak berwenang COVID-19 sudah mereda dan dapat dilakukan konsentrasi banyak orang, maka dapat dilaksanakan dengan tetap memperhatikan petunjuk dan ketentuan yang dikeluarkan pihak berwenang mengenai hal itu. Adapun kumandang takbir 'Id dapat dilakukan di rumah masing-masing selama darurat COVID-19 [Lihat dalil pada angka 7]. ${ }^{36}$

Untuk melengkapi seruan tersebut, PP Muhammadiyah juga mengeluarkan secara khusus Edaran Pimpinan Pusat Muhammadiyah Nomor 04/EDR/I.0/E/2020 tentang Tuntunan Shalat Idul Fitri dalam Kondisi darurat Pandemi COVID 19, tertanggal 21 Ramadhan 1441 H/14 Mei 2020 serta ditandatangani oleh tertanggal dan ditandatangani oleh Ketum PP Muhammadiyah Haedar Nashir dan Sekretaris PP Muhammadiyah Agung Danarto. Tuntunan Shalat I'edulfitri dalam Masa Darurat Pandemi Covid-19, merupakan hasil pembahasan dari Majelis Tarjih dan Tajdid PP Muhammadiyah, yang ditandangani oleh Ketua Majelis Tarjih dan Tajdid PP Muhammadiyah Prof.Dr.H.Syamsul Anwar, MA., dan sekretarisnya Drs. Mohammad Mas'udi, MA. Sikap terkait dengan penyelenggaraan shalat Idul Fitri ini dinyatakan pada poin 6a dan b, yaitu:a)Apabila pada tanggal 1 Syawal $1441 \mathrm{H}$ yang akan datang kedaan negeri Indonesia oleh pihak berwenang (pemerintah) belum dinyatakan bebas dari pandemi Covid-19 dan aman untuk berkumpul orang banyak maka Shalat Idulfitri di lapangan sebaiknya ditiadakan atau tidak dilaksanakan. Hal itu untuk memutus rantai mudarat persebaran virus korona tersebut agar kita cepat terbebas daripadanya dan dalam rangka saddu $\mathbf{z}-\mathbf{Z}$ ari ${ }^{-}$ah (tindakan preventif) guna menghindarkan kita jatuh ke dalam kebinasaan seperti diperingatkan dalam Al-Quran (Q 2: 195) dan demi menghindari mudarat seperti

${ }^{35}$ Lihat Hasil Babtsul Masail Lembaga Bahtsul Masail PB NU tentang Pelaksanaan Shalat Id di Rumah, tertanggal 20 Mei 2020

${ }^{36}$ Lihat kembali Surat Edaran Pimpinan Pusat Muhammadiyah No. 03/EDR/I.0/E/2020 tentang Tuntunan Ibadah dalam Kondisi Darurat COVID-19 
ditegaskan dalam sabda Nabi saw yang sudah dikutip dalam "Tuntunan Ibadah dalam Kondisi Darurat Covid-19," yang disebut terdahulu. b.)Karena tidak dapat dilaksanakan secara normal di lapangan sebagaimana mestinya, lantaran kondisi lingkungan belum dinyatakan oleh pihak berwenang bersih (clear) dari COVID-19 dan aman untuk berkumpul banyak orang, maka Shalat I'ed bagi yang menghendaki dapat dilakukan di rumah masing-masing bersama anggota keluarga dengan cara yang sama seperti Shalat I'ed di lapangan. Bahkan sebaliknya, tidak ada ancaman agama atas orang yang tidak melaksanakannya, karena Shalat I'ed adalah ibadah sunah. ${ }^{37}$

Ditegaskan pula pada poin 6 surat edaran ini yakni bahwa pelaksanaan Shalat I'ed di rumah tidak membuat suatu jenis ibadah baru. Shalat I'ed ditetapkan oleh Nabi saw melalui sunahnya. Shalat I'ed yang dikerjakan di rumah adalah seperti Shalat yang ditetapkan dalam sunah Nabi saw. Hanya tempatnya dialihkan ke rumah karena pelaksanaan di tempat yang semestinya, yaitu di lapangan yang melibatkan konsentrasi orang banyak, tidak dapat dilakukan. Juga tidak dialihkan ke masjid karena halangannya adalah ketidakmungkinan berkumpulnya orang banyak di suatu tempat. Karena terhalang di tempat yang semestinya, yakni di lapangan, maka dialihkan ke tempat di mana mungkin dilakukan, yakni di rumah. ${ }^{38}$

Sementara itu, terkait dengan penyelenggaraan Shalat I'ed di masa pandemi COVID-19 ini MUI juga mengeluarkan fatwa khusus. Yaitu Fatwa Majelis Ulama Indonesia Nomor: 28 Tahun 2020 Tentang Panduan Kaifiat Takbir dan Shalat Idul Fitri Saat Pabdemi COVID-19. Dalam fatwa tersebut disebutkan pada ketentuan dan panduan hukum pada bagian II Ketentuan Pelaksanaan Shalat Idul Fitri di Kawasan COVID-19. Ketentuan ini berisi 1) Shalat Idul Fitri boleh dilaksanakan dengan cara berjamaah di tanah lapang, masjid, mushalla, atau tempat lain bagi umat Islam yang: a. berada di kawasan yang sudah terkendali pada saat 1 Syawal $1441 \mathrm{H}$, yang salah satunya ditandai dengan angka penularan menunjukkan kecenderungan menurun dan kebijakan pelonggaran aktifitas sosial yang memungkinkan terjadinya kerumunan berdasarkan ahli yang kredibel dan amanah. b. berada di kawasan terkendali atau kawasan yang bebas COVID-19 dan diyakini tidak terdapat penularan (seperti di kawasan pedesaan atau perumahan terbatas yang homogen, tidak ada yang terkena COVID-19, dan tidak ada keluar masuk orang). 2) Shalat Idul Fitri boleh dilaksanakan di rumah dengan berjamaah bersama anggota keluarga atau secara sendiri (munfarid), terutama yang berada di kawasan penyebaran COVID-19 yang belum terkendali. 3) Pelaksanaan shalat Idul Fitri, baik di masjid maupun di rumah harus tetap melaksanakan protokol kesehatan dan mencegah terjadinya potensi

37 Lihat Edaran Pimpinan Pusat Muhammadiyah Nomor 04/EDR/I.0/E/2020 tentang Tuntunan Shalat Idul Fitri dalam Kondisi Darurat Pandemi COVID 19

38 Lihat kembali Edaran Pimpinan Pusat Muhammadiyah Nomor 04/EDR/I.0/E/2020 tentang Tuntunan Shalat Idul Fitri dalam Kondisi Darurat Pandemi COVID 19

36 | Jurnal Muttaqien: e-ISSN : 2723-5963 
penularan, antara lain dengan memperpendek bacaan shalat dan pelaksanaan khutbah. $^{39}$

Dalam hal umat melaksanakan shalat Idul Fitri di rumah, disebutkan dalam ketentuan dan panduan hukum bagian V. Ketentuan Shalat Idul Fitri Di Rumah Ketentuan ini memuat berbagai hal sebagai berikut: 1) Shalat Idul Fitri yang dilaksanakan di rumah dapat dilakukan secara berjamaah dan dapat dilakukan secara sendiri (munfarid). 2) Jika shalat Idul Fitri dilaksanakan secara berjamaah, maka ketentuannya sebagai berikut: a. Jumlah jamaah yang shalat minimal 4 orang, satu orang imam dan 3 orang makmum. b. Kaifiat shalatnya mengikuti ketentuan angka III (Panduan Kaifiat Shalat Idul Fitri Berjamaah) dalam fatwa ini. c. Usai shalat Id, khatib melaksanakan khutbah dengan mengikuti ketentuan angka IV dalam fatwa ini. d. Jika jumlah jamaah kurang dari empat orang atau jika dalam pelaksanaan shalat jamaah di rumah tidak ada yang berkemampuan untuk khutbah, maka shalat Idul Fitri boleh dilakukan berjamaah tanpa khutbah. ${ }^{40}$

Hadirnya berbagai kebijakan organisasi dalam bentuk instruksi, hasil musyawarah organisasi, fatwa, maupun surat edaran ini dapat memandu umat untuk melaksanakan pilihan pelaksanaan peribadatan sesuai dengan keyakinannya dan dikaitkan dengan kedaruratan situasi di masa pandemi. Sehingga mereka merasa mempunyai arahan dalam menjalankan berbagai pilihan ini.

\section{4) Pengurusan Jenazah Pasien COVID-19}

Pengurusan jenazah pasien COVID-19 merupakan isu sentitif yang seringkali menghadirkan ketegangan di masyarakat. Baik terkait keluarga pihak yang meninggal, maupun masyarakat di sekitarnya. Kasus penjemputan paksa jenazah pasien COVID19 sebagaimana yang telah diuraikan dalam latar belakang penelitian, menunjukkan bahwa ada konflik keagamaan yang terjadi di masyarakat akibat salah paham tentang pengelolaan jenazah. Oleh karenanya, ormas keagamaan Islam memiliki peran penting di dalam menjelaskan soal pengelolaan jenazah pasien COVID-19 yang tentunya berbeda dengan pengelolaan jenazah pada umumnya.

Oleh karena itu, menjawab kegelisahan ini, NU melalui Lembaga Bahtsul Masail PB NU telah mengeluarkan Hasil Bahtsul Masail PB NU tentang Fiqh Pemulasaraan Jenazah Pasien COVID-19, tertanggal 21 Maret 2020, ditandatangani oleh Ketua LBM PB NU KHMNajib Hassan dan Sekretaris LBM PB NU Sarmidi Husna, MA. Hasil bahtsul masail ini untuk menjawab pertanyaan publik mengenai apakah jenazah pasien Covid-19 yang Muslim harus dimandikan dan dirawat sebagaimana aturan syariat terhadap jenazah biasa, dan bagaimana cara memandikan dan menguburnya? Dalam hasil pembahasannya dinyatakan bahwa manusia adalah

\footnotetext{
${ }^{39}$ Fatwa Majelis Ulama Indonesia Nomor: 28 Tahun 2020 Tentang Panduan Kaifiat Takbir dan Shalat Idul Fitri Saat Pabdemi COVID-19. Fatwa Majelis Ulama Indonesia

40 Fatwa Majelis Ulama Indonesia Nomor: 28 Tahun 2020 Tentang Panduan Kaifiat Takbir dan Shalat Idul Fitri Saat Pabdemi COVID-19.
} 
makhluk yang sempurna, dan Karamah insaniyah tersebut salah satunya tercermin dalam تجهيز الميت (pemulasaraan jenazah: memandikan, mengkafani, menshalati dan menguburkan) yang menjadi kewajiban fakultatif ( فرض كفاية ) yang tertuju kepada umat Islam untuk setiap mayit Muslim. Mengingat situasi pandemi COVID-19 dan keadaan jenazah pasien COVID-19 tidak selalu dapat dilaksanakan sebagaimana mestinya, oleh karena itu Lembaga Bahtsul Masail menyatakan ketentuan tajhizul mayyit (pemulasaraan jenazah) pasien Covid-19 sebagai berikut: 1) Bahwa COVID19 merupakan wabah (tho'un), karena itu orang yang meninggal akibat Covid-19 statusnya adalah syabid fil akbiroh. Sebab kedudukan syahadah (mati syahid) tidak hanya didapat oleh mereka yang gugur di medan perang. Mereka yang meninggal karena wabah penyakit (tho'un) juga dapat meraih kedudukan syahadah. 2) Jenazah pasien Covid-19 muslim memiliki kedudukan dan perlakuan sama dengan jenazah muslim pada umumnya, yaitu wajib dimandikan, dikafani, dishalati, dan dimakamkan. 3) Cara memandikan jenazah pasien Covid-19 dengan menggunakan peralatan yang bisa mencegah penularan penyakit tersebut. Memandikan dilakukan oleh orang yang profesional atau petugas kesehatan dengan harus melindungi diri dan memastikan keamanannya (menggunakan pakaian pelindung, sarung tangan, masker, dan desinfeksi diri) agar tidak tertular virus dari jenazah. Setelah dimandikan, jenazah pasien COVID-19 dibungkus kain kafan kemudian dibungkus sejenis plastik sehingga tidak mudah tercemar. Dan secara terperinci dapat mengikuti ketentuan berikut: a) Jika menurut ahli memandikan jenazah COVID-19 dengan cara standar tersebut masih membahayakan bagi yang memandikan atau penyebaran virusnya, maka jenazah tersebut boleh dimandikan dengan cara menuangkan air ke badan jenazah saja, tanpa dalku (digosok). b)Jika hal itu tidak bisa dilakukan juga, maka boleh tidak dimandikan dan diganti dengan ditayamumkan.c) Dan jika hal itu juga tidak dapat dilakukan karena dalam kondisi darurat, maka jenazah boleh langsung dikafani dan disholati, tanpa dimandikan atau ditayamumkan. Karena kondisi darurat atau sulit tersebut, maka boleh mengambil langkah kemudahan (al-masyaqqoh tajlibut taisir). 4) Untuk protokol atau teknis mengkafan jenazah pasien COVID-19 secara ekstra dan pemakamannya harus mengikuti arahan dari para ahli medis. ${ }^{41}$

Sementara itu, sikap Muhammadiyah tentang pemulasaraan jenazah Pasien COVID-19 juga telah diatur dalam Surat Edaran Pimpinan Pusat Muhammadiyah No. 03/EDR/I.0/E/2020 tentang Tuntunan Ibadah dalam Kondisi Darurat COVID-19. Pada poin no. 15 dinyatakan bahwa Perawatan jenazah pasien COVID-19 sejak meninggal dunia sampai dikuburkan, dilakukan sesuai dengan standar protokol kesehatan yang dikeluarkan oleh pihak berwenang, misalnya Keputusan Menteri Kesehatan Republik Indonesia No. 300/ Perawatan jenazah pasien COVID-19 sejak meninggal dunia sampai dikuburkan, dilakukan sesuai dengan standar protokol

${ }^{41}$ Hasil Bahtsul Masail PB NU tentang Fiqh Pemulasaraan Jenazah Pasien COVID-19, tertanggal 21 Maret 2020, ditandatangani oleh Ketua LBM PB NU KHMNajib Hassan dan Sekretaris LBM PB NU Sarmidi Husna, MA

38 | Jurnal Muttaqien: e-ISSN : 2723-5963 
kesehatan yang dikeluarkan oleh pihak berwenang, misalnya Keputusan Menteri Kesehatan Republik Indonesia No. 300/ Menkes/SK/IV/2009 tentang Pedoman Penanggulangan Episenter Pandemi Influenza Butir B. 3. 6). Respon Medik dan Laboratorium: Pencegahan dan Pengendalian Infeksi, Surveillans, dan Pemulasaraan Jenazah dan Surat Edaran Direktorat Jendral Bimbingan Masyarakat Islam Kementerian Agama Republik Indonesia Nomor P-002/DJ.III/Hk.00.7/032020 tentang Imbauan dan Pelaksanaan Protokol Penanganan COVID-19 pada Area Publik di Lingkungan Direktorat Jendral Bimbingan Masyarakat Islam Kementerian Agama Republik Indonesia Butir E.4 Imbauan Pelaksanaan Protokol Pengurusan Jenazah Pasien COVID-19.Pada poin no. 16 dinyatakan Apabila dipandang darurat dan mendesak, jenazah dapat dimakamkan tanpa dimandikan dan dikafani, dalam rangka menghindarkan tenaga penyelenggara jenazah dari paparan COVID-19 dengan pertimbangan asas-asas hukum syariah bahwa Allah tidak membebani hamba-Nya kecuali sejauh yang mampu dilakukannya, apa yang diperintahkan Nabi saw dilaksanakan sesuai dengan kemampuan, tidak ada kemudaratan dan pemudaratan, kemudaratan harus dihilangkan, kesulitan memberikan kemudahan, keadaan mendesak dipersamakan dengan keadaan darurat, dan kemudaratan dibatasi sesuai dengan kadarnya, dan mencegah mudarat lebih diutamakan daripada mendatangkan maslahat. Kewajiban memandikan dan mengafani jenazah adalah hukum kondisi normal, sedangkan dalam kondisi tidak normal dapat diberlakukan hukum darurat. Dan pada poin 17 dinyatakan bahwa penyelenggaraan Shalat jenazah dapat diganti dengan Shalat gaib di rumah masing-masing. Adapun kegiatan takziah dilakukan secara terbatas dengan memperhatikan hal-hal yang terkait penanggulangan COVID-19 atau dilakukan secara daring. ${ }^{42}$

Sementara itu, terkait dengan pengurusan jenazah MUI juga mengeluarkan Fatwa Majelis Ulama Indonesia Nomor: Nomor: 18 Tahun 2020 Tentang Pedoman Pengurusan Jenazah (Tajhiz, al-Janaiz) Muslim yang Terinfeksi COVID-19. Fatwa ini hadir karena pertimbangan antara lain: a) bahwa COVID-19 termasuk jenis penyakit berbahaya dan dapat menular kepada yang melakukan kontak dengan orang yang terpapar COVID-19 atau cara penularan lainnya; b) bahwa ketika pasien COVID-19 meninggal, maka virusnya masih ada di tubuhnya dan berbahaya yang dapat menular kepada orang yang melakukan kontak dengan jenazah tersebut dalam proses pengurusannya; c) bahwa muncul pertanyaan tentang tata cara pengurusan jenazah muslim pasien COVID-19 yang meliputi memandikan, mengafani, menyalatkan, dan mengebumikan sebagaimana aturan syariat terhadap jenazah pada umumnya; d) bahwa oleh karena itu dipandang perlu menetapkan fatwa tentang Pedoman Pengurusan Jenazah (Tajbir al-Jana'iv) Muslim yang Terinfeksi COVID-19 ${ }^{43}$

42 Surat Edaran Pimpinan Pusat Muhammadiyah No. 03/EDR/I.0/E/2020 tentang Tuntunan Ibadah dalam Kondisi Darurat COVID-19.

${ }^{43}$ Fatwa Majelis Ulama Indonesia Nomor: Nomor: 18 Tahun 2020 Tentang Pedoman Pengurusan Jenazah (Tajbiz. al-Janaiv) Muslim yang Terinfeksi COVID-19 
Dengan merujuk berbagai macam referensi baik Alquran, Hadits, pendapat para ulama, maupun pertimbangan medis, akhirnya MUI mengeluarkan ketentuan hukum tentang pengurusan jenazah muslim yang terinfeksi COVID-19 yang cukup detail. Yaitu:1)Menegaskan kembali Ketentuan Fatwa MUI Nomor 14 Tahun 2020 angka 7 yang menetapkan: "Pengurusan jenazah (tajhiz, al-jana'iz) yang terpapar COVID-19, terutama dalam memandikan dan mengafani harus dilakukan sesuai protokol medis dan dilakukan oleh pihak yang berwenang, dengan tetap memperhatikan ketentuan syariat. Sedangkan untuk menshalatkan dan menguburkannya dilakukan sebagaimana biasa dengan tetap menjaga agar tidak terpapar COVID-19." 2) Umat Islam yang wafat karena wabah COVID-19 dalam pandangan syara' termasuk kategori syahid akbirat dan hak-hak jenazahnya wajib dipenuhi, yaitu dimandikan, dikafani, dishalati, dan dikuburkan, yang pelaksanaannya wajib menjaga keselamatan petugas dengan mematuhi ketentuanketentuan protokol medis; 3) Pedoman memandikan jenazah yang terpapar COVID-19 dilakukan sebagai berikut: a. Jenazah dimandikan tanpa harus dibuka pakaiannya b. Petugas wajib berjenis kelamin yang sama dengan jenazah yang dimandikan dan dikafani; c. Jika petugas yang memandikan tidak ada yang berjenis kelamin sama, maka dimandikan oleh petugas yang ada, dengan syarat jenazah dimandikan tetap memakai pakaian. Jika tidak, maka ditayamumkan. d. Petugas membersihkan najis (jika ada) sebelum memandikan; e. Petugas memandikan jenazah dengan cara mengucurkan air secara merata ke seluruh tubuh; f. Jika atas pertimbangan ahli yang terpercaya bahwa jenazah tidak mungkin dimandikan, maka dapat diganti dengan tayamum sesuai ketentuan syariah, yaitu dengan cara: 1 . Mengusap wajah dan kedua tangan jenazah (minimal sampai pergelangan) dengan debu. 2.Untuk kepentingan perlindungan diri pada saat mengusap, petugas tetap menggunakan APD. g. Jika menurut pendapat ahli yang terpercaya bahwa memandikan atau menayamumkan tidak mungkin dilakukan karena membahayakan petugas, maka berdasarkan ketentuan dlarurat syar'iyyah, jenazah tidak dimandikan atau ditayamumkan. 4) Pedoman mengafani jenazah yang terpapar COVID-19 dilakukan sebagai berikut: a. Setelah jenazah dimandikan atau ditayamumkan, atau karena dlarurah syar'iyah tidak dimandikan atau ditayamumkan, maka jenazah dikafani dengan menggunakan kain yang menutup seluruh tubuh dan dimasukkan ke dalam kantong jenazah yang aman dan tidak tembus air untuk mencegah penyebaran virus dan menjaga keselamatan petugas. b. Setelah pengafanan selesai, jenazah dimasukkan ke dalam peti jenazah yang tidak tembus air dan udara dengan dimiringkan ke kanan sehingga saat dikuburkan jenazah menghadap ke arah kiblat. c. Jika setelah dikafani masih ditemukan najis pada jenazah, maka petugas dapat mengabaikan najis tersebut. 5)Pedoman menyalatkan jenazah yang terpapar COVID-19 dilakukan sebagai berikut: a. Disunnahkan menyegerakan shalat jenazah setelah dikafani. b. Dilakukan di tempat yang aman dari penularan COVID-19. c. Dilakukan oleh umat Islam secara langsung (hadhir) minimal satu orang. Jika tidak memungkinkan, boleh dishalatkan di kuburan sebelum atau sesudah dimakamkan. 
Jika tidak dimungkinkan, maka boleh dishalatkan dari jauh (shalat ghaib). d. Pihak yang menyalatkan wajib menjaga diri dari penularan COVID-19. 6)Pedoman menguburkan jenazah yang terpapar COVID-19 dilakukan sebagai berikut: a. Dilakukan sesuai dengan ketentuan syariah dan protokol medis. b. Dilakukan dengan cara memasukkan jenazah bersama petinya ke dalam liang kubur tanpa harus membuka peti, plastik, dan kafan. c. Penguburan beberapa jenazah dalam satu liang kubur dibolehkan karena darurat (al-dlarurah al-syar'iyyah) sebagaimana diatur dalam ketentuan Fatwa MUI nomor 34 tahun 2004 tentang Pengurusan Jenazah (Tajhiz alJana'iz) Dalam Keadaan Darurat. ${ }^{44}$

\section{5) Beragam Inisiatif menyikapi Tradisi Keagamaan dengan Cara Berbeda}

Menyikapi seruan pemerintah untuk stay at home dan social distancing selama pandemi COVID-19 serta beragam edaran ormas keagamaan untuk meminimalisir kegiatan yang bersifat kumpul-kumpul atau pertemuan, masyarakat juga beradaptasi dengan mengoptimalkan pertemuan melalui media online/daring. Sekedar untuk menyebutkan beberapa contoh, di Surabaya, Masjid Al -Akbar Surabaya menyelenggarakan kegiatan Ngabuburit Online. Mereka melantunkan shalawat Thibbil Qulub, mengikuti khataman online, yang disambungkan melalui Zoom. ${ }^{45}$ Di Tangerang Selatan, ITB Ahmad Dahlan menggelar kegiatan Ngabuburit Online melalui diskusi via zoom meeting, salah satunya adalah diskusi yang mengusung tema "Back to Normal or Going to the New Normal?: Masa Depan Kehidupan Warga Tangerang Selatan di Tengah Ancaman Virus Covid-19" 46

Kegiatan Tahlil yang seringkali dilakukan(Nurpratiwi, 2021) oleh warga Nahdliyyin pun digelar secara online. Contohnya, PC NU Kota Semarang yang menggelar Tahlilan untuk mendiang Ibu Sudjiatmi Notomiharjo, ibu Presiden RI Joko Widodo yang berpulang Maret lalu ${ }^{47}$ Bahkan peringatan Peringatan 100 Hari Wafatnya KH. Salahuddin Wahid (Gus Sholah), juga digelar secara online dan

${ }^{44}$ Lihat Fatwa Majelis Ulama Indonesia Nomor: Nomor: 18 Tahun 2020 Tentang Pedoman Pengurusan Jenazah (Tajbiz, al-Janaiz) Muslim yang Terinfeksi COVID-19

45 Omy (Dimas Ganjar, ed), Ngabuburit Online di MAS, Jamaah dengar Ceramah lewat Live Streaming, Jawa Pos.com, 26 April 2020, sebagaimana diunduh dari situs https://www.jawapos.com/surabaya/26/04/2020/ngabuburit-online-di-mas-jamaah-dengar-ceramahlewat-live-streaming/

46 Tim Seputar Tangsel, (Sugih Hartanto, ed.), Ngabuburit Online ITB Abmad Dablan: Back to Normal or Going to the New Normal?, SeputarTangsel.com, 9 Mei 2020, sebagaimana diunduh dari situs https:// seputartangsel.pikiran-rakyat.com/tangerang-selatan/pr-

14379484/ngabuburit-online-itb-ahmad-dahlan-back-to-normal-or-going-to-the-newnormal

${ }^{47}$ Lihat pemberitaan Antara (Lalu Ratri Mubyarsyah, ed.), PCNU Kota Semarang Gelar Tablil Online untuk Ibunda Jokowi, 26 Maret 2020, sebagaimana diunduh dari situs https://www.jawapos.com/jpgtoday/26/03/2020/pcnu-kota-semarang-gelar-tahlil-online-untuk-ibunda-jokowi/ 
disiarkan secara live streaming dan dapat disimak melalui Youtube. ${ }^{48}$ Pasca Idul Fitri, yang dilaksanakan di rumah saja atau secara berjamaah dengan secara terbatas dan mentaati protokol kesehatan, masyarakat tidak lagi saling mengunjungi dan bersalaman. Namun mereka bersilaturahmi dengan keluarga antara lain dengan menggelar video call ataupun halal bihalal melalui zoom. Media online, menjadi pilihan mereka untuk menyambung tali silaturahmi. Situasi dan cara ini juga yang disarankan oleh MUI. Sebagaimana yang disampaikan oleh MUI Jakarta, yang mengimbau agar halal bihalal bisa dilakukan secara online. ${ }^{49}$

Selain pembahasan di atas, pada masa penelitian ini dilakukan (terkait kebijakan yang beredar antara Maret-Mei 2020), hanya Majelis Ulama Indonesia (MUI) lah yang telah membahas soal adaptasi kebiasaan baru atau yang populer dengan istilah New Normal'. Kebijakan ini hadir melalui Maklumat Dewan Pimpinan Majelis Ulama Indonesia (DP MUI) tentang Rencana Pemberlakuan Kehidupan Normal Baru (New Normal Life) di Tengah Pandemi COVID-19. ${ }^{50}$

\section{Simpulan}

Dari berbagai hasil penelitian yang penulis paparkan, serta upaya untuk menjawab pertanyaan penelitian, dapat disimpulkan bahwa:

1) Umumnya komunikasi publik yang dilakukan oleh ormas keagamaan Islam (dalam hal ini NU, Muhammadiyah, dan MUI) dalam menyikapi isu social distancing di masa Pandemi COVID-19 ini adalah melalui sikap/keputusan resmi organisasi. Keputusan dan Sikap Resmi Organisasi ini. Dalam penelitian ini ditemukan 12 jenis keputusan organisasi, yakni 4 dikeluarkan oleh Nahdlatul Ulama (NU), 3 dikeluarkan oleh Muhammadiyah, dan 5 dikeluarkan oleh Majelis Ulama Indonesia (MUI)

2) Beberapa isu terkait social distancing yang dibahas oleh keduabelas kebijakan organisasi tersebut antara lain mengenai soal wabah COVID-19 dan pencegahan penularannya, kebijakan umum untuk menghindari kegiatan sosial keagamaan (shalat berjama'ah, silaturahmi, pengaiian, dan berbagai kegiatan sosial keagamaan lainnya) yang berpotensi memunculkan kerumuman karena pertemuan orang secara langsung dalam jumlah banyak, dan meresponnya dengan penatalaksaan pelaksanaan ibadah selama pandemi COVID-19. Antara lain mengatur soal shalat jama'ah, shalat Jum'at, shalat Idul Fitri, dan pengurusan jenazah.

48 Do'a dan Tahlilan Online, Peringatan 100 Hari W afatnya KH. Salahuddin Wabid (Gus Sholab), sebagaimana diunduh dari situs https: / / wmw.youtube.com / watch? $v=8 q n A 1 M z a G 6 s$

${ }^{49}$ Melia Istighfaroh, ed., MUI Jakarta Imbau Warga Lakukan Halal Bihalal Lebaran di Tengab Pandemi COVID-19 via Online, Tribun News.Com, 18 Mei 2020, sebagaimana diunduh dari situs https://www.tribunnews.com/nasional/2020/05/18/mui-jakarta-imbau-warga-lakukan-halal-bihalallebaran-di-tengah-pandemi-covid-19-via-online

${ }^{50}$ Lihat dalam Maklumat Dewan Pimpinan Majelis Ulama Indonesia (DP MUI) tentang Rencana Pemberlakuan Kebidupan Normal Baru (New Normal Life) di Tengah Pandemi COVID-19, Nomor: Kep-1188/DPMUI/V/2020, dikeluarkan pada tanggal 5 Syawal 1441 H/28 Mei 2020, ditandatangani oleh Wakil Ketua Umum KH. Muhyiddin Junaedi dan Sekretaris Jendral Drs.H.Anwar Abbas, MM.

42 | Jurnal Muttaqien: e-ISSN : 2723-5963 
3) Materi atau pesan yang dikomunikasikan biasanya menjawab pertanyaan publik yang bersifat praktis, terkait praktik ibadah dan pelaksanaan kegiatan sosial keagamaan. Misalnya, dalam kondisi pandemi apakah sebaiknya shalat di rumah atau di masjid/musholla, haruskah melaksanakan Shalat Jum'at atau Shalat Dhuhur, bolehkah melaksanakan shalat dengan cara berjama'ah atau melaksanakan shalat Jum'at pada wilayah yang masih belum terjangkit pandemi atau belum dinyatakan sebagai zona merah penularan wabah oleh pihak yang berwenang, bagaimana hukum dan tata cara menyelenggarakan shalat Idul Fitri selama pandemi.

4) Respon masing-masing ormas dalam menyampaikan pesan itu kepada publik juga cukup beragam. Misalnya, Nahdlatul Ulama (NU). Posisi PB NU lebih memberikan Instruksi yang bersifat umum dengan mengeluarkan Protokol NU Peduli COVID-19, sementara terkait dengan pengaturan teknis yang lainnya, misalnya pengelolaan pesantren, detail pengaturan dikeluarkan oleh Rabithah M'ahid al-Islamiyah (RMI) sebagai asosiasi pesantren di kalangan NU. Sementara, terkait dengan penyelenggaraan ibadah, seperti Shalat Idul Fitri dan Pemulasaraan Jenazah, pembahasan teknis dan keputusannya dikeluarkan oleh Lembaga Bahtsul Masail (LBM) PB NU. Sementara itu, Muhammadiyah meresponnya dengan mengeluarkan Maklumat tentang Corona Virus Disease sebagai panduan umum warganya, Surat Edaran tentang Tata Cara Pelaksanaan Ibadah selama Masa Pandemi COVID-19, dan secara lebih teknis membuat Surat Edaran tentang Pelaksanaan Shalat Idul Fitri sebagai respon atas pelaksanaan hari besar Islam. Adapun Majelis Ulama Indonesia (MUI) meresponnya dengan mengeluarkan berbagai Fatwa yang lebih teknis, dengan merujuk pada dalil-dalil keagamaan seperti alQur'an, al-Hadits, qaul ulama', dan kaidah fiqbiyyah lainnya serta hasil konsultasi dengan pihak yang berwenang (misalnya Kementerian Kesehatan). Jadi sifatnya lebih praktis dan menjawab kebutuhan umat sesuai dengan pertanyaan umat yang ditujukan kepada mereka. Hal ini tercermin pada materi fatwanya tentang penyelenggaraan ibadah dalam situasi wabah COVID-19, pedoman Pengurusan Jenazah pasien muslim yang terinfeksi COVID-19, dan panduan dan kaifiat penyelenggaraan Takbir dan Shalat Idul Fitri. Di antara ketiga lembaga tersebut, MUI paling cepat merespon isu 'new normal' dengan mengeluarkan Maklumat Dewan Pimpinan MUI tentang Rencana Pemberlakuan Kehidupan Normal Baru (New Normal). Sungguh pun hal ini terasa agak berbeda, mengingat biasanya MUI melakukan pertimbangan yang mendalam dan hadir ke tengah publik dengan Fatwa-nya.

5) Selain menggunakan sikap resmi organisasi sebagai bentuk komunikasi publiknya, ketiga ormas ini juga menyampaikan sikapnya melalui media yang biasanya diwakili oleh Ketua atau pun para pengurusnya. Namun materi komunikasi publik yang mereka sampaikan, lebih merupakan sebagian dari isi sikap resmi yang sudah dibahas oleh masing-masing organisasi. Para pimpinan organisasi ini (di berbagai levelnya) juga telah mulai memberikan contoh untuk bisa berkomunikasi dan bersosialisasi dalam situasi social distancing, dengan menginisiasi atau pun terlibat dalam berbagai online event baik untuk ngabuburit saat bulan Ramadhan, halal bihalal, bahkan tahlil. Hal ini juga menginspirasi 
berbagai pihak untuk mengoptimalkan silaturahmi dan membuat kegiatan keagamaan secara virtual, saat pandemi COVID-19 masih terjadi.

Dari proses yang peneliti lakukan saat meneliti maupun menulis hasil penelitian ini, peneliti menemukan bahwa masih banyak hal menarik yang bisa dilanjutkan maupun dikembangkan oleh peneliti lainnya. Di antaranya adalah soal komunikasi publik pada ormas keagamaan Islam sendiri tentu memiliki bentuk dan isu yang bervariasi, yang tentunya bisa didalami oleh peneliti dari disiplin ilmu Komunikasi Penyiatan Islam. Adapu tentang bagaimana proses pengambilan hukum di masing-masing organisasi atau istimbath al-abkam menarik untuk diteliti oleh para peneliti dari disiplin ilmu Syariah dan Hukum Islam.

Terkait dengan isu-isu yang peneliti temukan dalam penelitian ini, misalnya soal penyelenggaraan ibadah selama pandemi (baik soal pelaksanaan shalat berjamaah, shalat Jum'at, maupun penyelenggaraan jenazah pasien muslim yang terpapar virus COVID-19), ketaatan anggota atau jamaah organisasi keagamaan Islam pada kebijakan organisasinya terkait dengan protokol COVID-19. Juga inisiatif-inisiatif untuk menggantikan tradisi pertemuan sosial keagamaan (pengaiian, tahlil, khataman, dll.) yang biasanya berlangsung secara tatap muka, melalui media daring (online). Berbagai isu ini, bisa didekati dari perspektif monodisiplin maupun interdisipliner. Akhir kata, semua penelitian diharapkan ini bermanfaat baik bagi dunia akademik maupun memberi manfaat praktis dalam kehidupan sosial kemasyarakatan kita. Wallabu a'lam bish-shawab...

\section{Daftar Pustaka}

Alex Sobur, Analisis Teks Media: Suatu Pengantar Analisis Wacana, Analisis Semiotik, dan Analisis Framing, Remaja Rosdakarya, Cetakan kedelapan, Oktober 2018, Bandung.

Elvinaro Ardianto, Lukiati Komala, dan Siti Karlinah, Komunikasi Massa: Suatu Pengantar, Simbiosa Rekatama Media, Edisi Revisi Oktober 2015, Bandung

Dadan Suherdiana*, Aang Ridwan, Uwes Fatoni, Rojudin berjudul Pesan Dakwah Ormas Islam Indonesia dalam Menghadapi Krisis Keagamaan Masa Pandemi Covid-19, pada Program Studi Komunikasi dan Penyiaran Islam, UIN Sunan Gunung Djati Bandung), 2020

Dani Muhtada, Agama dan Mitigasi Wabah COVID-19 (CSIS Commentaries, DMRU-011, 23 Maret 2020).

Edaran Pimpinan Pusat Muhammadiyah Nomor 04/EDR/I.0/E/2020 tentang Tuntunan Shalat Idul Fitri dalam Kondisi Darurat Pandemi COVID 19

Effendi, M. R. (2020). Mitigasi Intoleransi dan Radikalisme Beragama di Pondok Pesantren Melalui Pendekatan Pembelajaran Inklusif. Paedagogie| Jurnal Pendidikan dan Studi Islam, 1(1), 56-75.

Effendi, M. R. (2020). Mitigasi Intoleransi dan Radikalisme Beragama di Pondok Pesantren Melalui Pendekatan Pembelajaran Inklusif. Paedagogie, I(I), 55-74. https://doi.org/doi.org/10.20211/pdg.01.1.05 
Muhamad Agus Mushodiq dan Ali Imron Peran Majelis Ulama Indonesia Dalam Mitigasi Pandemi Covid-19 (Tinjauan Tindakan Sosial dan Dominasi Kekuasaan Max Weber) yang diterbitkan oleh SALAM; Jurnal Sosial \& Budaya Syar-i FSH UIN Syarif Hidayatullah Jakarta Vol. 7 No. 5 (2020)

Maklumat Dewan Pimpinan Majelis Ulama Indonesia (DP MUI) tentang Rencana Pemberlakuan Kehidupan Normal Baru (New Normal Life) di Tengah Pandemi COVID-19, Nomor: Kep-1188/DP-MUI/V/2020, dikeluarkan pada tanggal 5 Syawal 1441 H/28 Mei 2020, ditandatangani oleh Wakil Ketua Umum KH. Muhyiddin Junaedi dan Sekretaris Jendral Drs.H.Anwar Abbas, MM.

Instruksi PB NU tentang Protokol NU Peduli COVID 19, dikeluarkan pada 12 Maret 2020/17 Rajab $1441 \mathrm{H}$, ditandatangani oleh Ketua Umum Prof.Dr. Said Agil Siraj dan Sekretaris Jenderal Dr.Ir.H.A Helmy Faisal Zaini dan Pejabat Rais Aam KH Miftahul Ahyar dan Katib Aam KH Yahya Kholil Staquf Instruksi PB NU tentang Protokol NU Peduli COVID 19, dikeluarkan pada 12 Maret 2020/17 Rajab 1441 H, ditandatangani oleh Ketua Umum Prof.Dr. Said Agil Siraj dan Sekretaris Jenderal Dr.Ir.H.A Helmy Faisal Zaini dan Pejabat Rais Aam KH Miftahul Ahyar dan Katib Aam KH Yahya Kholil Staquf

Surat Edaran Pimpinan Pusat Muhammadiyah No. 03/EDR/I.0/E/2020 tentang Tuntunan Ibadah dalam Kondisi Darurat COVID-19 tertanggal 7 Sya'ban 1441H/31 Maret 2020 dan ditandatangani olehtertanggal dan ditandatangani oleh Ketum PP Muhammadiyah Prof. Dr. H. Haedar Nashir, MA dan Sekretaris PP Muhammadiyah Dr.H. Agung Danarto, MA

Hasil Babtsul Masail Lembaga Babtsul Masail PB NU tentang Pelaksanaan Shalat Id di Rumah, tertanggal 20 Mei 2020. Hasil Bahtsul Masail ini ditandatangani oleh Ketua LBM PB NU KH M. Najib Hassan dan Sekretaris LBM PB NU Sarmidi Husna, MA.

Hasil Babtsul Masail PB NU tentang Fiqh Pemulasaraan Jenazah Pasien COVID-19, tertanggal 21 Maret 2020, ditandatangani oleh Ketua LBM PB NU KHM Najib Hassan dan Sekretaris LBM PB NU Sarmidi Husna, MA

Fatwa Majelis Ulama Indonesia Nomor: 14 Tahun 2020 Tentang Penyelenggaraan Ibadab dalam Situasi Wabah COVID-19.

Fatwa Majelis Ulama Indonesia Nomor. 31 Tahun 2020 tentang Penyelenggaraan Shalat Jum'at dan Jama'ah untuk. Mencegah Penularan Wabah COVID-19

Fatwa Majelis Ulama Indonesia Nomor: Nomor: 18 Tahun 2020 Tentang Pedoman Pengurusan Jenazah (Tajbiz al-Janaiz) Muslim yang Terinfeksi COVID-19

Nurpratiwi, M. R. E. dan S. (2021). Hubungan Keberagamaan dan Perilaku Altruistik Mahasiswa. Al-Afkar, 4(1), 83-97.

https://doi.org/https://doi.org/10.31943/afkarjournal.v4i1.181

Surat Maklumat Pimpinan Pusat Muhammadiyah, No.02/MLM/I.0/H/2020 tentang Wabah Corona Virus Disease 
Surat Edaran Nomor : 835/A/PPRMI/SE/III/2020TANGGAL : 13 Maret 2020 M / 18 Rajab $1441 \mathrm{H}$ tentang Protokol Pencegaban Penyebaran CORONA VIRUS DISEASE 19 (COVID-19) pada Pondok Pesantren. Dikeluarkan oleh PP. Rabithah Ma'ahid Islamiyah (Asosiasi Pesantren Nahdhatul Ulama), ditandatangani oleh Ketua RMI H.Abdul Ghofarrozin dan Sekretaris RMI Habib Sholeh

\section{Dari Internet:}

Antara (Lalu Ratri Mubyarsyah, ed.), PCNU Kota Semarang Gelar Tablil Online untuk Ibunda Jokowi, 26 Maret 2020, sebagaimana diunduh dari situs https://www.jawapos.com/ipgtoday/26/03/2020/pcnu-kota-semarang-gelar-tahlil-online-untuk-ibunda-jokowi/

Bonfilio Mahendra Wahanaputra Ladjar (Sandro Gatra, ed.), Tiga Jemaah Positif Covid-19, Sekitar 170 Orang Diisolasi di Masjid di Taman Sari, sebagaimana ditayangkan di Kompas.com, 27 Maret 2020. Pemberitaan ini juga bisa dibaca di: https://megapolitan.kompas.com/read/2020/03/27/22403151/tiga-jemaah-positifcovid-19-sekitar-170-orang-diisolasi-di-masjid-di?page=all.

CNN Indonesia, Kamis, 19/03/2020, Diimbau Ditunda, Pentahbisan Uskup Ruteng Tetap Digelar, sebagaimana diunduh dari situs: https://www.cnnindonesia.com/nasional/20200319081813-20-484797/diimbauditunda-pentahbisan-uskup-ruteng-tetap-digelar

Do'a dan Tahlilan Online, Peringatan 100 Hari Wafatnya KH. Salabuddin Wabid (Gus Sholah), sebagaimana diundub dari situs https: / www.youtube.com / watch? $v=8$ qnA1MzaG6s

Gun Gun Heryanto, Komunikasi Wabab Corona, artikel pada Republika, 23/03/2020

Hari Widowati, Kominfo Temukan 25 Hoaks tentang Korona, 31/1/2020 yang dapat diakses melalui www.katadata.co.id

Liputan6, 3/4/2020

Kompas.com, 13/4/2020

Kompas.com, 26/3/2020

Melia Istighfaroh, ed., MUI Jakarta Imbau Warga Lakukan Halal Bibalal Lebaran di Tengah Pandemi COVID-19 via Online, Tribun News.Com, 18 Mei 2020, sebagaimana diunduh dari situs https://www.tribunnews.com/nasional/2020/05/18/mui-jakarta-imbauwarga-lakukan-halal-bihalal-lebaran-di-tengah-pandemi-covid-19-via-online

Okezone.com, 30/3/2020

Olivia Hernanda, , Menimbang Peran Media dalam Menghadapi Epidemii, pada rubrik Amatan, yang diterbitkan oleh Remotivi pada 3/3/2020 yang dapat diakses pada www.remotivi.id

Omy (Dimas Ganjar, ed), Ngabuburit Online di MAS, Jamaah dengar Ceramah lewat Live Streaming, Jawa Pos.com, 26 April 2020, sebagaimana diunduh dari situs 
https://www.jawapos.com/surabaya/26/04/2020/ngabuburit-online-di-masjamaah-dengar-ceramah-lewat-live-streaming

Pebriansyah Ariefana, Ijtima Ulama Asia di Gowa Batal, MUI: Untuk Kepentingan Norma Agama, Kamis, 19 Maret 2020, pada suara.com; sebagaimana dikip dari situs https://www.suara.com/news/2020/03/19/105318/ ijtima-ulama-asia-di-gowabatal-mui-untuk-kepentingan-norma-agama

Tim Seputar Tangsel, (Sugih Hartanto, ed.), Ngabuburit Online ITB Abmad Dablan: Back to Normal or Going to the New Normal? SeputarTangsel.com, 9 Mei 2020, sebagaimana diunduh dari situs https://seputartangsel.pikiranrakyat.com/tangerang-selatan/pr-14379484/ngabuburit-online-itbahmad-dahlan-back-to-normal-or-going-to-the-new-normal 